\title{
Review of Constructed Wetlands for Acid Mine Drainage Treatment
}

\author{
Aurora M. Pat-Espadas ${ }^{1, * \mathbb{D}}$, Rene Loredo Portales ${ }^{1}{ }^{\mathbb{D}}$, Leonel E. Amabilis-Sosa ${ }^{2}$, Gloria Gómez ${ }^{3}$ \\ and Gladys Vidal ${ }^{3}$ (D) \\ 1 CONACYT-UNAM Instituto de Geología, Estación Regional del Noroeste (ERNO), Luis D. Colosio y \\ Madrid, 83000 Hermosillo, Sonora, Mexico; rloredop@geologia.unam.mx \\ 2 CONACYT-Instituto Tecnológico de Culiacán, Unidad de Posgrado e Investigación, Av. Juan de Dios Bátiz \\ s/n,80220 Culiacán, Sinaloa, Mexico; leoamabilis@gmail.com \\ 3 Engineering and Environmental Biotechnology Group, Environmental Sciences Faculty and EULA-Chile \\ Center, Universidad de Concepción, Concepción 4070386, Chile; margaritapat@hotmail.com (G.G.); \\ glvidal@udec.cl (G.V.) \\ * Correspondence: apespadas@geologia.unam.mx or aurorampatespadas@gmail.com; \\ Tel.: +52-662-2175019 (ext. 118); Fax: +52-662-2175340
}

Received: 11 October 2018; Accepted: 8 November 2018; Published: 19 November 2018

\begin{abstract}
The mining industry is the major producer of acid mine drainage (AMD). The problem of AMD concerns at active and abandoned mine sites. Acid mine drainage needs to be treated since it can contaminate surface water. Constructed wetlands (CW), a passive treatment technology, combines naturally-occurring biogeochemical, geochemical, and physical processes. This technology can be used for the long-term remediation of AMD. The challenge is to overcome some factors, for instance, chemical characteristics of AMD such a high acidity and toxic metals concentrations, to achieve efficient CW systems. Design criteria, conformational arrangements, and careful selection of each component must be considered to achieve the treatment. The main objective of this review is to summarize the current advances, applications, and the prevalent difficulties and opportunities to apply the $\mathrm{CW}$ technology for AMD treatment. According to the cited literature, sub-surface $\mathrm{CW}$ (SS-CW) systems are suggested for an efficient AMD treatment. The synergistic interactions between $\mathrm{CW}$ components determine heavy metal removal from water solution. The microorganism-plant interaction is considered the most important since it implies symbiosis mechanisms for heavy metal removal and tolerance. In addition, formation of litter and biofilm layers contributes to heavy metal removal by adsorption mechanisms. The addition of organic amendments to the substrate material and AMD bacterial consortium inoculation are some of the strategies to improve heavy metal removal. Adequate experimental design from laboratory to full scale systems need to be used to optimize equilibria between CW components selection and construction and operational costs. The principal limitations for CW treating AMD is the toxicity effect that heavy metals produce on CW plants and microorganisms. However, these aspects can be solved partially by choosing carefully constructed wetlands components suitable for the AMD characteristics. From the economic point of view, a variety of factors affects the cost of constructed wetlands, such as: detention time, treatment goals, media type, pretreatment type, number of cells, source, and availability of gravel media, and land requirements, among others.
\end{abstract}

Keywords: acid mine drainage; constructed wetland; passive treatment; metal removal

\section{Physical-Chemical and Toxicological Characterization of Acid Mine Drainage}

Acid mine drainage (AMD) forms when sulfide minerals are exposed to oxidizing conditions during and following mining operations, highway construction, and other large-scale excavations $[1,2]$. 
Although wastewaters with this composition are produced by different industrial operations, the mining industry is the major producer of such effluents [3]. Oxidation of sulfidic rocks in open pits, dumps, and reservoirs/tailings deposits, and operating effluents generated during the extraction processes of minerals are the main sources of contamination by mining activity.

In the extraction processes, the volume of waste varies with the ore processed. In the case of extraction of $\mathrm{Pb}-\mathrm{Zn}$ from massive sulfide-rich rocks, between 60 and $80 \%$ constitute waste; in the extraction of $\mathrm{Cu}$ from porphyry, $97 \%-99.5 \%$ of the rock is discarded and in the case of gold, only $1 \%$ of the extracted rock is processed [4]. When the residues are forming sulfides, their exposure to oxygen and water, accompanied by microbial activity leads to the formation of sulfate, metal, and acid drainage called AMD.

The oxidation of metal sulfides is generally explained by pyrite $\left(\mathrm{FeS}_{2(\mathrm{~s})}\right)$, the most abundant mineral:

$$
\mathrm{FeS}_{2(\mathrm{~s})}+\frac{15}{4} \mathrm{O}_{2}+\frac{7}{2} \mathrm{H}_{2} \mathrm{O} \rightarrow \mathrm{Fe}(\mathrm{OH})_{3(\mathrm{~S})}+2 \mathrm{SO}_{4}^{2-}+4 \mathrm{H}^{+}
$$

The decrease in $\mathrm{pH}$, due to oxidized pyrite, can accelerate the oxidation of other sulfuric minerals, such as stibnite, argentite, and stannite. Moreover, the AMD can leach metals/ecotoxic metalloids from geological materials. The resultant ecotoxic ions and acidity are significant threats to water resources [5]. The formation of AMD will depend on interactions between the microbiology and the mineralogical and geochemical conditions of the site [4]; in the case of limestone and silicates, these can attenuate the contamination (by increasing the $\mathrm{pH}$ and/or affecting the solubility of metals).

The formation of acid drainage is a complex geochemical and microbially mediated process, function of microbiological controls, depositional environment, acid/base balance of the overburden, lithology, mineralogy, and mine site hydrologic conditions $[2,6]$.

The potential for a mine or its associated waste to generate acid and release contaminants depends on site-specific factors that can be categorized in three: generation factors (water, oxygen, bacteria), chemical control factors (ability of the rock or receiving water to either neutralize the acid or to change the effluent character by adding metals ions mobilized by residual acid), and physical factors (particle size, permeability, and physical weathering characteristics, hydrology) (Figure 1).
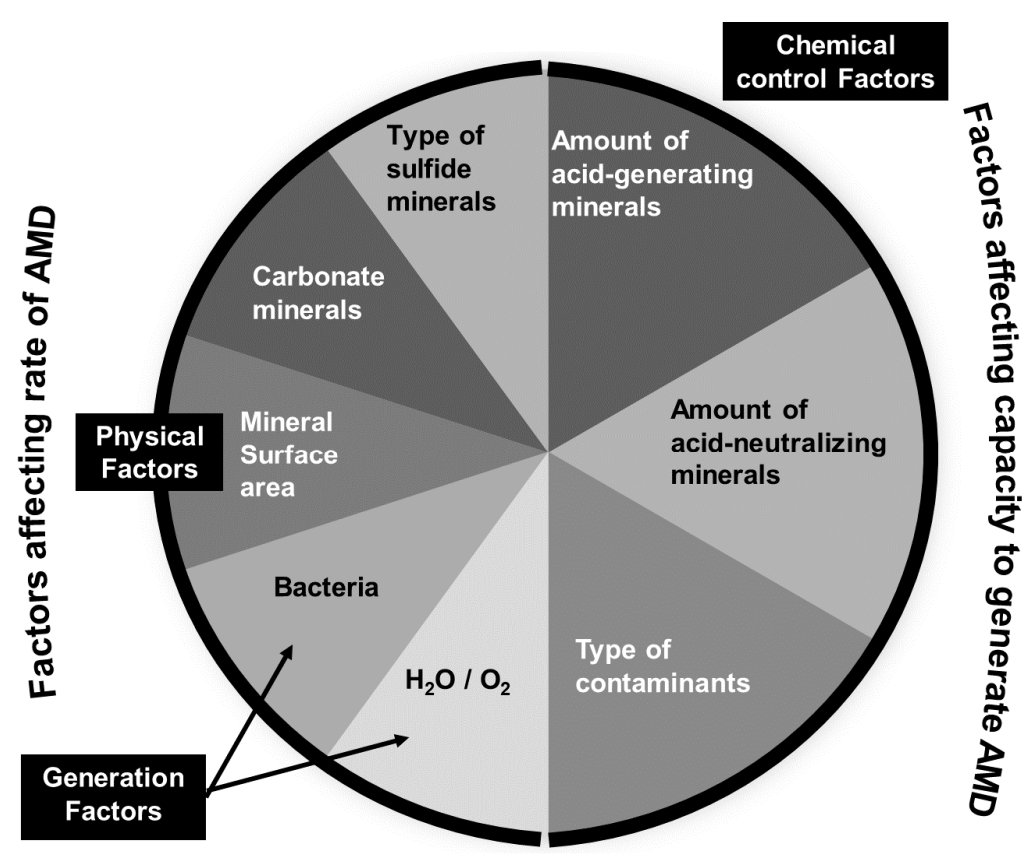

Figure 1. Factors that influence the formation of acid drainage. 
There are methods to determine if a discrete volume of mining waste will generate acid and predict the quality of the drainage based on the rate of acid formation measured [7]. The results obtained from these methods can help to design an appropriate treatment system. Methods can be either static or kinetic tests. The former, predict drainage quality by comparing the sample maximum acid production potential (AP) with its maximum neutralization potential (NP) obtaining the net neutralization potential $(\mathrm{NNP}), \mathrm{NNP}=\mathrm{NP}-\mathrm{AP}$. A value of NNP $<0$ indicates potential for the waste to form acid while a value of NP $>0$ represents lower risk [8]. Examples of static tests includes acid base accounting (ABA), modified acid base accounting, British Columbia Research Initial Test (BC), alkaline production potential: sulfur ratio (APP:S) and net acid production test (NAP). On the other hand, kinetic tests attempt to mimic natural oxidation reactions of the field setting and provide information on the rate of sulfide mineral oxidation and acid production. Tests such as humidity cell, soxhelet extraction, column, British Columbia Research Confirmation, batch reactor, and field scale are examples of kinetic tests. Results from static and kinetic tests are used to classify mine wastes on the basis of their potential to generate acid [8].

Acid mine drainage has a high content of iron (Equation (1)), and sulfate promotes the oxidation of sulfur minerals bound to metals such as $\mathrm{As}, \mathrm{Cd}, \mathrm{Co}, \mathrm{Cu}, \mathrm{Pb}$, and $\mathrm{Zn}$ [9]. Of all the pollutants of the watercourses, perhaps AMD is one of the most serious, due to its nature, extent, and difficulty of resolution. The rivers and aquifers affected by this type of pollution are characterized by their acidity, as well as by the high content of sulfates and heavy metals in their waters by the metallic content of their sediments [5]. Internationally, AMD and liquid waste generated during the extraction and processing of minerals under the term water impacted by mining (MIW) are grouped. The management, storage, and disposal of MIW is a major environmental problem in all mining areas [10]. Acid mine drainage is a persistent problem at active but also is an important problem at abandoned mine sites. From this perspective, countries such as Australia, the United States, and Canada consider monitoring programs that have enabled the cadastre of environmental liabilities to be developed and remedied. Due to this, Table 1 details the metal content of some aquifers contaminated with mining drainages in Germany, USA, Canada, Malaysia, Zimbabwe, among others.

The information provided in Table 1 is quite broad regarding the range in which the different minerals can be found in the MIW. As an example, it can be indicated that the concentration of $\mathrm{SO}_{4}{ }^{2-}$ can vary between $19 \mathrm{mg} / \mathrm{L}$ (Mamut Mine, Malaysia) and $108 \mathrm{~g} / \mathrm{L}$ (Aquifer near the Richmond mine). However, it is possible to state that all spills and/or discharges of MIW have acid characteristic (range $\mathrm{pH}$ 0.5-7.0).

High concentrations of metals can affect freshwater species, including microalgae, microcrustaceans, and fish [11]. An ecotoxicological assessment of mine water usually starts by assessing the concentrations of metals (e.g., $\mathrm{Fe}, \mathrm{Mn}, \mathrm{Cu}, \mathrm{As}, \mathrm{Ba}, \mathrm{Cd}, \mathrm{Zn}, \mathrm{Ni}$, and $\mathrm{Pb}$ ) [12]. Metal distribution, speciation, and bioavailability in sediments and the water column can have deep impact by AMD toxicity. The environmental effects could be evaluated by biological assays using different species as it is mentioned in the following paragraphs [13].

Daphnia species $(s p)$ have been used in standard toxicity tests for many years due to their high sensitivity, manageability, and high parthenogenetic reproduction rate, which ensures a uniform response [14,15]. Furthermore, these species play an important role in the aquatic food chain [16]. Daphnia sp. are non-selective filter-feeders, thus, the process of feeding has a direct influence on the physiological performance in terms of growth, metabolism, and reproduction [17]. On the other hand, most metals are plant growth inhibitors, exerting various adverse effects leading to phytotoxic responses and to decreased yield and quality of agricultural crops [18]. Phytotoxic effects caused by metals are related to oxidative stress. Concentrations between 1.5 and $10 \mathrm{mM}$ of $\mathrm{Cu}$ and/or $\mathrm{Zn}$ inhibit germination and early growth of barley, rice, and wheat [19]. $\mathrm{Cu}, \mathrm{Zn}$, and other elements interfere with cellular division, diminish respiration at the roots, reduce water intake, and alter the transport and metabolism of various essential nutrients. As a consequence, inhibition in germination and in elongation of the radicle and epicotyl are determinant final points for assessment of AMD phytotoxic 
effects [20]. Chamorro et al. (2018) and Villamar et al. (2014) showed that the phytotoxic effects caused by metals produce an oxidative stress that inhibits germination. The AMD toxicity was evaluated on Lactuca sativa (lettuce), Raphanus sativus (radish), and Triticum aestivum (wheat), the results, expressed as the fraction of AMD resulting in 50\% lethality (Lethal Concentration- $-\mathrm{LC}_{50}$ ) at $144 \mathrm{~h}$, showed that wheat was more tolerant $\left(\mathrm{LC}_{50}=62 \%\right)$ than radish $\left(\mathrm{LC}_{50}=17.0 \%\right)$ or lettuce $\left(\mathrm{LC}_{50}=21 \%\right)$. Also, $\mathrm{AMD}$ has been found to be very toxic to Daphnia magna (cladoceran) and Danio rerio (zebrafish) embryos, two of the best model organisms in aquatic ecology and ecotoxicology $\left(\mathrm{LC}_{50}<1 \%\right)$ [21]. However, waters and soils of mine areas can be treated to avoid or minimize environmental damage.

The aim of this article is to present a broad perspective of the constructed wetlands CWs technology applied to the treatment of AMD to achieve high metal removal efficiencies. This review focuses on summarizing the main aspects of the mechanisms prevailing in these systems for metal removal, and the design and operation conditions are also presented in order to offer insights on how all the aspects can be adjusted for the characteristics of AMD.

Constructed wetlands systems are not a new technology but they are currently the most widely-used passive mine water treatment technology.

In the following sections the types of CWs, operational parameters, heavy metal uptake mechanisms by plants, microorganisms, and support material are emphasized and explained. 
Table 1. Species content (mg/L) and $\mathrm{pH}$ of groundwater contaminated with MIW.

\begin{tabular}{|c|c|c|c|c|c|c|c|c|c|}
\hline Description & $\mathrm{pH}$ & $\mathrm{SO}_{4}{ }^{2-}$ & As & Cd & $\mathrm{Cr}$ & $\mathrm{Cu}$ & $\mathbf{F e}$ & Zn & Ref. \\
\hline Underground water near Königstein mine, Germany \# & 5.9 & 33 & & & $<0.02$ & & 1.5 & $<0.01$ & [22] \\
\hline Unsaturated area near the Königstein mine, Germany * & 1.9 & 12,322 & & & 0.97 & & 1171 & 132 & [22] \\
\hline Aquifer near the Richmond mine, USA & $0.5-1$ & $20,000-108,000$ & $3-222$ & $4.0-19.0$ & & $120-650$ & $13,000-19,000$ & $700-2600$ & [23] \\
\hline Aquifer affected by Carlton mine, USA & 7 & 1292 & & & & & 0.01 & 0.04 & {$[24]$} \\
\hline Groundwater from different locations in the Cae mine, Canada & $1.9-2.3$ & $19-265$ & & & & $0.04-37$ & $31,570-1100$ & $1.3-120.0$ & [25] \\
\hline Mine Mamut, Malaysia & 2.6 & 14.8 & & & & 299 & 443 & 90 & [26] \\
\hline Groundwater close to iron mine, Zimbabwe & 1.5 & 355,425 & 72 & 3.7 & 18 & 20 & 132,909 & 55 & [26] \\
\hline
\end{tabular}

Presence of $\mathrm{Pb}$ and Uranium in concentrations $0.01 \mathrm{mg} / \mathrm{L}$ and less than $0.02 \mathrm{mg} / \mathrm{L} ;{ }^{*}$ Presence of $\mathrm{Pb}$ and Uranium in concentrations $2.1 \mathrm{mg} / \mathrm{L}$ and $12.3 \mathrm{mg} / \mathrm{L}$, respectively. 


\section{Constructed Wetlands Applied to AMD Treatment: Types, Operational Parameters, and Efficiency}

Treatment of AMD can be accomplished by either active or passive techniques. The former refers to the improvement of water quality by methods which require ongoing inputs of artificial energy and/or chemical reagents. On the other hand, passive techniques refer to the deliberate improvement of water quality using only naturally-available energy sources (e.g., gravity, microbial metabolic energy, photosynthesis) in systems which require only infrequent (although regular) maintenance in order to operate effectively over the entire system design life [27]. In practice, AMD active treatment refers to (though not exclusively) the continuous application of alkaline materials to neutralize acidic mine waters and precipitate metals, and passive treatment to the use of natural and constructed wetland ecosystems [28].

The origin of current passive mine water treatment technologies can be traced, to two independent observations in the eastern USA $[29,30]$, to the effect that Sphagnum bogs naturally improved the quality of coal mine waters flowing into them [27]. These studies constitute the first attempts to construct wetlands specifically to treat polluted mine waters. Wetlands have the capacity to improve water quality by physical, chemical, microbial, and plant-mediated processes. These include oxidation, reduction, precipitation, sedimentation, filtration, adsorption, complexation, chelation, active plant uptake of metals and microbial conversion/immobilization mechanisms [31,32]. Constructed wetlands mimic the functions of natural wetlands with the objective to treat water. Typical components of $\mathrm{CW}$ are: soil bottom, vegetation, water surface, and it can also contain some kind of media (rock, gravel, soil, or others) [33].

There are two main criteria to classify constructed wetlands: water flow regime (surface and sub-surface) and type of macrophytic growth. Constructed wetlands with surface flow (water a relatively shallow depth, water is exposed directly to the atmosphere, circulating between the stems and leaves of the vegetation) can be classified according to the type of macrophytes (emergent, submerged, free floating and floating-leaved plants) [34].

SS-CW consists of a sealed basin, water level is below ground ( 0.3 to $0.9 \mathrm{~m}$ deep); water flow is through a sand or gravel bed; and roots penetrate to the bottom of the bed. According to the flow direction of the influent, they are divided into horizontal sub-surface flow wetlands and vertical flow SS-CW [34].

There are also hybrid or combined systems that incorporate different types of CW with the aim of exploiting the specific advantages of the different systems arrangements.

Constructed wetland systems are currently the most widely-used passive mine water treatment technology for at least four reasons: (i) aerobic wetlands are a proven technology in treating net-alkaline mine waters (iron as only pollutant), (ii) low cost compared to active treatment systems, (iii) have the ability of large wetland systems to cope with unforeseen fluctuations, and (iv) have landscape amenities of appeal to human visitors [27]. However, some characteristics of AMD such as high acidity and toxic metals concentrations are challenging for $\mathrm{CW}$ systems, but design criteria, conformational arrangements, and careful selection of each component must be considered to achieve the treatment.

Table 2 summarizes reports regarding the use of CW for AMD treatment to achieve metal removal. Constructed wetland systems have been used both at full scale to treat real AMD water near to mine sites and also at small or lab-scale in the pursuit of finding better conditions for higher metal removal efficiencies.

As it is shown, operational parameters are roughly reported, some studies reported hydraulic retention time but not the hydraulic load, etc. Under this scenario the comparison between the systems cannot be fair; however, some general conclusions about some aspects can be made.

Analyzing the performance of the type of wetland used, it can be observed that for some metals the removal efficiency varies when using surface or SS-CW. For instance, better removal had been achieved for $\mathrm{Al}, \mathrm{Mn}, \mathrm{Ni}$, and $\mathrm{Zn}$ [35-38] in SS-CW as compared to surface CW. On the other hand, 
metals such as Fe can be removed efficiently by both types of CW systems with efficiencies up to $92.0 \%$ (Table 2).

In the attempt to achieve higher removal efficiencies different strategies can be applied to this technology. For example, the combining of surface flow wetlands with SS-CW (hybrid system) have been used. The study by Stottmeister and colleagues [39] demonstrated that this system can be successfully applied for As and Zn simultaneous removal. Actually, for the treatment of AMD with the presence of metals with high toxicity, such as $\mathrm{Pb}$ and $\mathrm{As}$, in concentrations exceeding international guidelines, by CW, only surface flow CW and hybrids have been used. Nevertheless, only hybrid CW systems had been implemented for long term at small scale $[39,40]$.

An important aspect regardless the type of artificial wetland and metals in the AMD, is that, according to the studies, at a $\mathrm{pH}$ value higher than 4.2 the removal efficiencies tend to be lower $[35,39]$, in fact, at alkaline conditions the removal efficiencies are reported to be less than $34 \%$ [36].

Other studies have tested the use of combined substrate, for instance soil $(75 \%)$, powdered goat manure $(20 \%)$, and wood shavings $(5 \%)$ in surface CW. The combined substrate used in the study by Sheoran (2017) was reported to promote sulfate reduction leading to an increase in $\mathrm{pH}$ from 3.16 to 7.20 and heavy metal removal from the AMD as a consequence [35].

The strategy of combining the mine effluent with wastewater can also be considered. Türker et al. (2013) [41] used small-scale, polyculture SS-CW to treat mine effluent (metal content of B, Ca, Mn, and $\mathrm{Na})$ mixed with municipal wastewater $(\mathrm{DQO}=62.1 \mathrm{mg} / \mathrm{L})$. This study was performed at small scale under field conditions.

Regarding vegetation, studies revealed that species such as Typha latifolia, Phragmites australis, and Juncus effuses are the most used plants; however, it is not a rule and other species have been tested achieving good result for instance, Desmostachya bipinnata. Plant density is another parameter that is poorly described but it can be crucial for the correct performance of the system.

Since the CW system has different components, the metal removal is expected to occur in more than one of them, such as soil and substrate, and influenced by hydrology and vegetation [36] through different mechanisms. Moreover, the number and diversity of microorganisms found in each CW component is dependent of different factors such as wastewater type and characteristics, geography, among others, which are observed to influence the kinetics of metals removal [37].

Some studies have focused on report metal removal by analyzing water samples but just some of them have analyzed all the CW constituents (plants, media, water, etc.) to make a total balance and elucidate the contribution of each component. Hence, the knowledge and understanding of these main aspects based in scientific and practical experiences could lead to a better design and operation to achieve better results using the CW technology. In the following sections these aspects are explained and discussed in detail. 
Table 2. Types of constructed wetlands applied to metal removal from acid mine drainage and their operational characteristics.

\begin{tabular}{|c|c|c|c|c|c|c|}
\hline \multirow[b]{2}{*}{ Type of CW } & \multicolumn{2}{|c|}{ Influent Characteristics } & \multirow{2}{*}{$\begin{array}{l}\quad \begin{array}{l}\text { Operational } \\
\text { Parameters }\end{array} \\
\text { (a) HRT (d) } \\
\text { (b) Hydraulic load } \\
\left(\mathrm{m}^{3} / \mathrm{m}^{2} \cdot \mathrm{d}\right) \\
\text { (c) Scale }\end{array}$} & \multirow[b]{2}{*}{ Type of Vegetation } & \multirow[b]{2}{*}{$\begin{array}{l}\text { Removal Efficiency } \\
\text { of Metal (\%) }\end{array}$} & \multirow[b]{2}{*}{ Reference } \\
\hline & Metal (mg/L) & $\begin{array}{l}\text { (a) } \mathrm{SO}_{4}{ }^{2-}\left(\mathrm{mg} \mathrm{L}^{-1}\right) \\
\text { (b) } \mathrm{pH} \\
\text { (c) Alkalinity } \\
\text { (mg/L CaCO } \\
\text { (m) }\end{array}$ & & & & \\
\hline \multirow{4}{*}{ Surface Flow } & $\begin{array}{l}\text { Fe }(260.5 \pm 23.7) \\
\mathrm{Zn}(5.9 \pm 0.3) \\
\mathrm{Cu}(1.44 \pm 0.1) \\
\mathrm{Cd}(0.006 \pm 0.0)\end{array}$ & $\begin{array}{l}\text { (a) } 1336 \pm 5.0 \\
\text { (b) } 2.65 \pm 0.02 \\
\text { (c) } 0\end{array}$ & $\begin{array}{l}\text { (a) - } \\
\text { (b) } 0.033 \\
\text { (c) small-scale }\end{array}$ & $\begin{array}{c}\text { Carex rostrata } \\
\text { Eriophorum angustifolium } \\
\text { Phragmites australis }\end{array}$ & $\begin{array}{c}-0.8-0.4 \\
-3.4-8.5 \\
50-57\end{array}$ & [38] \\
\hline & $\begin{array}{l}\mathrm{Al}(30-100) \\
\mathrm{Ca}(-) \\
\mathrm{Fe}(200-250) \\
\mathrm{Mg}(30-100) \\
\mathrm{Mn}(30-100) \\
\mathrm{S}(-)\end{array}$ & $\begin{array}{l}\text { (a) } 500-1000 \\
\text { (b) } 2.6 \\
\text { (c) - }\end{array}$ & $\begin{array}{l}\text { (a) - } \\
\text { (b) - } \\
\text { (c) full-scale }\end{array}$ & Typhia latifolia & $\begin{array}{c}23-30 \\
5-8 \\
25-31 \\
17 \\
18-19 \\
17-18\end{array}$ & [39] \\
\hline & $\begin{array}{l}\mathrm{Fe}(12.0) \\
\mathrm{Al}(11.3) \\
\mathrm{Zn}(0.385) \\
\mathrm{Ni}(0.388) \\
\mathrm{Cu}(0.03) \\
\mathrm{Pb}(0.01)\end{array}$ & $\begin{array}{l}\text { (a) } 2610 \\
\text { (b) } 2.54-2.99 \\
\text { (c) - }\end{array}$ & $\begin{array}{l}\text { (a) - } \\
\text { (b) - } \\
\text { (c) lab-scale }\end{array}$ & Chrysopogon zizanioides & - & [41] \\
\hline & $\begin{array}{l}\mathrm{Fe}(44-205 / 1.3) \\
\mathrm{Mn}(5.9-7.4 / 0.2) \\
\mathrm{Al}(0.02-0.29 / 0.1) \\
\mathrm{Zn}(<0.009-0.03 /<0.009) \\
\mathrm{Cd}(<0.006-0.02 /<0.006) \\
\mathrm{B}(0.01-1.17 /<0.006) \\
\mathrm{As}(0.0009-0.1 / 0.0004) \\
\mathrm{Pb}(<0.002-0.0022-<0.002)\end{array}$ & $\begin{array}{l}\text { (a) - } \\
\text { (b) } 6.3-7.2 / 5.7 \\
\text { (c) - }\end{array}$ & $\begin{array}{l}\text { (a) - } \\
\text { (b) } 113.68 / 302.69 / 928.8 \\
\text { (c) full-scale }\end{array}$ & $\begin{array}{l}\text { Scirpus cyperinus } \\
\text { Typha latifolia } \\
\text { Juncus effusus }\end{array}$ & $\begin{array}{c}97-98 / 10 \\
47-79 / 40 \\
- \\
33 /- \\
100 /- \\
52 /- \\
99-100 /- \\
26 /-\end{array}$ & [42] \\
\hline
\end{tabular}


Table 2. Cont

\begin{tabular}{|c|c|c|c|c|c|c|}
\hline \multirow[b]{2}{*}{ Type of CW } & \multicolumn{2}{|c|}{ Influent Characteristics } & \multirow{2}{*}{\begin{tabular}{l}
\multicolumn{1}{c}{$\begin{array}{l}\text { Operational } \\
\text { Parameters }\end{array}$} \\
(a) HRT (d) \\
(b) Hydraulic load \\
$\left(\mathrm{m}^{3} / \mathrm{m}^{2} \cdot \mathrm{d}\right)$ \\
(c) Scale
\end{tabular}} & \multirow[b]{2}{*}{ Type of Vegetation } & \multirow[b]{2}{*}{$\begin{array}{c}\text { Removal Efficiency } \\
\text { of Metal (\%) }\end{array}$} & \multirow[b]{2}{*}{ Reference } \\
\hline & Metal (mg/L) & $\begin{array}{l}\text { (a) } \mathrm{SO}_{4}{ }^{2-}\left(\mathrm{mg} \mathrm{L}^{-1}\right) \\
\text { (b) } \mathrm{pH} \\
\text { (c) Alkalinity } \\
\text { (mg/L CaCO } \\
\end{array}$ & & & & \\
\hline & $\begin{array}{l}\mathrm{Fe}(17.861) \\
\mathrm{Cu}(14.620) \\
\mathrm{Zn}(29.367) \\
\mathrm{Pb}(1.753) \\
\mathrm{Co}(0.323) \\
\mathrm{Ni}(0.388) \\
\mathrm{Mn}(2.143)\end{array}$ & $\begin{array}{l}\text { (a) } 395 \\
\text { (b) } 2.93-3.31 \\
\text { (c) } 0\end{array}$ & $\begin{array}{l}\text { (a) } 1,2,3,4,7 \\
\text { (b) - } \\
\text { (c) bench-scale }\end{array}$ & Desmostachya bipinnata & $\begin{array}{l}95-96 \\
89-92 \\
77-78 \\
89-90 \\
68-72 \\
30-64 \\
36-76\end{array}$ & [43] \\
\hline \multirow{4}{*}{ Subsurface flow } & $\begin{array}{l}\mathrm{Al}(12.6 \pm 4.1) \\
\mathrm{Fe}(787 \pm 121) \\
\mathrm{Mn}(10.9 \pm 2.1)\end{array}$ & $\begin{array}{l}\text { (a) - } \\
\text { (b) } 3.38 \pm 0.45 \\
\text { (c) - }\end{array}$ & $\begin{array}{l}\text { (a) - } \\
\text { (b) - } \\
\text { (c)full-scale }\end{array}$ & $\begin{array}{l}\text { Typha latifolia } \\
\text { Scirpus validus } \\
\text { Bidens aristosa }\end{array}$ & $\begin{array}{l}95.8 \\
99.9 \\
98.4\end{array}$ & {$[40]$} \\
\hline & $\begin{array}{l}\mathrm{B}(187) \\
\mathrm{Ca}(54.9) \\
\mathrm{Mn}(19.6) \\
\mathrm{Na}(318)\end{array}$ & $\begin{array}{l}\text { (a) - } \\
\text { (b) } 8.96 \\
\text { (c) - }\end{array}$ & $\begin{array}{l}\text { (a) } 15 \\
\text { (b) } 0.00078 \\
\text { (c) small-scale }\end{array}$ & $\begin{array}{c}\text { Typha latifolia } \\
\text { Phragmites australis }\end{array}$ & $\begin{array}{c}30-37 \\
20-25 \\
30-34 \\
30-33.5\end{array}$ & [38] \\
\hline & $\begin{array}{l}\mathrm{Fe}(1-191) \\
\mathrm{Al}(<1-48) \\
\mathrm{Ca}(64-170)\end{array}$ & $\begin{array}{l}\text { (a) } 312-1603 \\
\text { (b) } 3.4-6.1 \\
\text { (c) } 0-54\end{array}$ & $\begin{array}{l}\text { (a) } 2.4-27 \\
\text { (b) } 0.12-0.75 \\
\text { (c) full-scale }\end{array}$ & - & $\begin{array}{c}0-92 \\
0-90 \\
(-8)-(-57)\end{array}$ & {$[36]$} \\
\hline & $\begin{array}{l}\mathrm{Fe}(38.1) \\
\mathrm{Mn}(2.6) \\
\mathrm{Ni}(0.4) \\
\mathrm{Zn}(9.0)\end{array}$ & $\begin{array}{l}\text { (a) } 292-377 \\
\text { (b) } 4.2 \\
\text { (c) - }\end{array}$ & $\begin{array}{l}\text { (a) } 5 \\
\text { (b) } 0.01 \\
\text { (c) small-scale }\end{array}$ & Typhia latifolia & $\begin{array}{c}98.6 / 89.8 \\
75.5 /-20.3 \\
88.5 / 58.1 \\
96.7 / 96.3\end{array}$ & [43] \\
\hline \multirow{2}{*}{$\begin{array}{c}\text { Hybrid } \\
\text { (surface + subsurface } \\
\text { flow) }\end{array}$} & $\begin{array}{l}\mathrm{Zn}(1.8) \\
\text { As }(0.5)\end{array}$ & $\begin{array}{l}\text { (a) 2000-3000 } \\
\text { (b) } 3.0 \\
\text { (c) - }\end{array}$ & $\begin{array}{l}\text { (a) - } \\
\text { (b) Batch system } \\
\text { (c) small-scale }\end{array}$ & Juncus effusus & $\begin{array}{l}67 \\
98\end{array}$ & {$[44]$} \\
\hline & $\begin{array}{l}\text { Fe (166) } \\
\mathrm{Al}(83) \\
\mathrm{Mn}(250)\end{array}$ & $\begin{array}{l}\text { (a) } 1672 \\
\text { (b) } 2.73-3.08 \\
\text { (c) } 48-63.1\end{array}$ & $\begin{array}{l}\text { (a) } 12 \\
\text { (b) } 4.6 \\
\text { (c) full-scale }\end{array}$ & $\begin{array}{l}\text { Typha sp. } \\
\text { Typha latifolia }\end{array}$ & $\begin{array}{c}82.35 \\
61.25 \\
94.9\end{array}$ & [45] \\
\hline
\end{tabular}




\section{Heavy Metal Uptake Mechanisms in Constructed Wetlands}

In CW for AMD treatment systems metals are removed by a series of mechanisms that are usually attributed to a particular CW component. However, the removal of metals from aqueous solution comes from an interaction and synergetic effect between them. Each component of a CW system participates in metal removal: (i) the support material (mineral and/or organic) contributes to the removal mainly by adsorption processes, (ii) plants (emerging, floating and submerged) contribute mainly by direct uptake mechanisms, and (iii) microorganisms (bacteria and archaea) contribute by promoting reduction and subsequent precipitation of metals.

In this section, the role and removal mechanisms are described for each of these components, recommendations for better a performance are also mentioned.

\subsection{Role of Vegetation on the Removal of Heavy Metals}

Plants are one of the CW components whose participation can be underestimated. Despite the direct uptake, wetland plants act directly promoting adsorption and precipitation mechanisms assisted by bacteria and support material. Indirect contributions come from the formation of litter layer and organic particulate matter that contributes by trapping metals and lead to their sedimentation and by providing surface area and symbiosis between bacteria which promote mechanisms of metal reduction, adsorption, and precipitation. It is important to mention that wetland systems without plants are less efficient than those with vegetal material [46]. In this section plants' role in metal removal from acid solutions is described with emphasis in plant type and interactions between other $\mathrm{CW}$ components. Comments and recommendations to be considered for a better performance in metal removal are assessed.

\subsubsection{Factors Involved in Metal Uptake Efficiencies by Plants}

The plants commonly used in CW systems associated to mine drainage treatment are emergent, floating, and submerged plants. Emergent plants include species like P. australis, P. arundinacea, T. dominguensis, T. latifolia, P. karka, and P. australis [41,42,47]. The emergent plants promote the adsorption to the substrate and additionally they improve the removal by well know common processes like uptake and retention of heavy metals over its tissues. Floating plants, cannot promote the adsorption through the substrate, but they improve their adsorption to the plant biomass. Examples of floating plants includes species such as Echhornia crassipes, Pistia stratiotes, and Salvinia herzoggi. Finally, submerged plants, for instance, Potamogeton spp., Ceratophylum demersum, Myriophylum spicatum, and Hydrilla verticillata are suggested to be used on mine drainage treatment since they can accumulate metals in the hole biomass, but Fe precipitation over its roots can limit photosynthesis and their metal uptake [46].

Heavy metal removal efficiencies of $\mathrm{CW}$ are variable, and it depends on many factors, including AMD physical and chemical characteristics, support material composition, operation time, among others. According to the literature, to improve the plants performance on removal efficiencies, it is necessary to take into account the following approaches: (1) The use of local native plants is highly recommended, since they show better survival percentage and adaptation properties. For example, a CW treating Boron(B)-mine effluent and wastewater showed survival percentage of 87.5 and $100 \%$ of T. latifolia and P. australis obtained from natural wetland habitats at the same area, respectively [41]. However, this effect is more related to the variation of sensitivity to the environmental factors rather than metal tolerance properties [46]. (2) The plant growth stage in CW is also an important factor to improve heavy metal removal, since adult plants have much better ability to modify the environment and immobilize metals in the rhizosphere. In this stage, plants have much better developed aerenchymatous tissue, higher oxygen transport and a minor loss of radial oxygen. This also enhance the respiration of microbe in the rhizosphere promoting removal mechanisms by bacteria $[47,48]$. (3) The season, a parameter that cannot be controlled but that can 
be predicted and considered during the system design, also plays a role on the efficiency of heavy metal removal in $\mathrm{CW}$ since winter and summer weather have been shown a decreasing and increasing effect, respectively $[35,46,47]$. (4) The selection of the plant species is essential as metal uptake and accumulation capacities are specific and it has to be according to AMD characteristics in order to ensure the effectiveness of the system [41]. There are different reports with information about plants species and their accumulation towards specific heavy metals which can be consulted and considered for CW design [49-51]. For example, Leung et al. (2017) [47] compared the accumulation of Pb, Zn, and $\mathrm{Cd}$ concentrations in a $\mathrm{CW}$ receiving metals from mining facilities, where T. latifolia showed the highest content of these elements $\left(3.4,3.3,0.06\right.$, and $\left.0.01 \mathrm{~g} / \mathrm{m}^{2}\right)$, compared to C. Malacencis (2.5, $1.2,0.1$, and $\left.0.007 \mathrm{~g} / \mathrm{m}^{2}\right)$ and P. australis $\left(2.4,1.6,0.06\right.$, and $\left.0.006 \mathrm{~g} / \mathrm{m}^{2}\right)$. Türker et al. [41] also compared the accumulation of $\mathrm{B}$ by $T$. latifolia and $P$. australis in a polyculture $\mathrm{CW}$ receiving mining effluent, the results showed that T. latifolia can accumulate more B in its tissues $(250 \mathrm{mg} / \mathrm{Kg})$ than P. australis $(38 \mathrm{mg} / \mathrm{Kg}$ ). (5) Monoculture CWs have been reported more efficient for AMD treatment than polyculture CWs since the interspecific competition and overcrowding affects the nutrient availability and metal uptake rates [41].

Metals contained in AMD such as $\mathrm{Zn}, \mathrm{Cu}$, and Fe are reported as easy to remove in $\mathrm{CW}$ systems; conversely, elements like $\mathrm{Mn}, \mathrm{Ni}$, and $\mathrm{B}$ tend to be difficult to remove [35,41,42,46,52]. For instance, iron has been reported to be removed first from AMD solutions in bench scale studies, using Demostachya bippinata and organic substrate [43]. Some plant species, such as P. australis, has been shown to accumulate higher concentrations of Fe in roots and shoots $(1100-1600 \mathrm{mg} / \mathrm{Kg})$ [53]. Batty and Younger (2004) found that P. australis exposed to AMD show more Fe concentrations in its tissues, especially within or associated with plant roots, than those exposed to uncontaminated water [53].

Sulfate removal efficiencies in CW is still unclear, some authors report low or negligible removal [54] while other studies reported high rates of sulfate removal [43,55]. It has been reported that the presence of $T$. latifolia had a marginal effect on sulfate removal, but its carbon-rich litter greatly promoted sulfate removal [56].

Additionally, $\mathrm{pH}$ of the AMD is expected to influence the plant uptake content, for example B has shown a better uptake rate by plants of Hordeum vulgare in $\mathrm{pH}$ range from 6.3 to 7.5 and an inverse correlation between a $\mathrm{pH}$ increase and B plant tissue content [57].

Vegetation is an important component of CW used to treat AMD, plants produce synergy with other components, increasing the removal efficiencies for heavy metals. The principal mechanisms of plants in heavy metal removal includes: (1) chemical precipitation and sorption onto sediments assisted by macrophytes, (2) metal retention over plant tissues via filtration, adsorption, cation exchange, and changes induced in the rhizosphere, (3) retention and precipitation by symbiotic processes with root bacteria (e.g., formation of iron oxyhidroxydes layer, that also could adsorb other metals), and (4) direct uptake of metals by plant roots, (less than $2 \%$ of metals are reported to be uptake by plant roots, Marchand et al. (2010) [46], (see Figure 2). Other collateral processes are the accumulation of plant detritus or litter and suspended organic matter that act trapping metals [35,46,47,58,59].

On the other hand, most studies argued that plants generally have a low contribution on the heavy metal removal in CW, an argument generally based considering only the direct uptake mechanism and short time period experiments, where the participation of support material cover up the role of $\mathrm{CW}$ plants [53]. However, the role of plants as an essential component of constructed wetlands is well established and most studies comparing planted versus unplanted subsurface CW systems treating wastewaters, including AMD, show a significant and positive effect of pollutant removal by providing sites for metal precipitation and/or sedimentation $[55,60]$. Yet, most of the literature experiments do not include a control of unplanted units [53], hence comparison and conclusions about the importance of plants are difficult to state

The direct uptake by plants is usually calculated by measuring plant growth and metal content stored in plant tissues [53]. However, in big scale systems plant uptake tends to be negligible and difficult to measure at least in short time operations. Leung et al. (2017) [47] measured heavy metal 
concentrations in $\mathrm{CW}$ components receiving water from mining facilities and less than $0.1 \%$ of the removal of $\mathrm{Pb}, \mathrm{Zn}, \mathrm{Cu}$, and $\mathrm{Cd}$ was associated to accumulation in the $\mathrm{CW}$ plants tissues.

Another important issue regarding plants in CW treating mine water is the presence of phytotoxic concentration metals, which can affect the plant growth, or create problems associated with reduced nutrient uptake due to the presence of high concentrations of metals and $\mathrm{H}^{+}$ions [61].

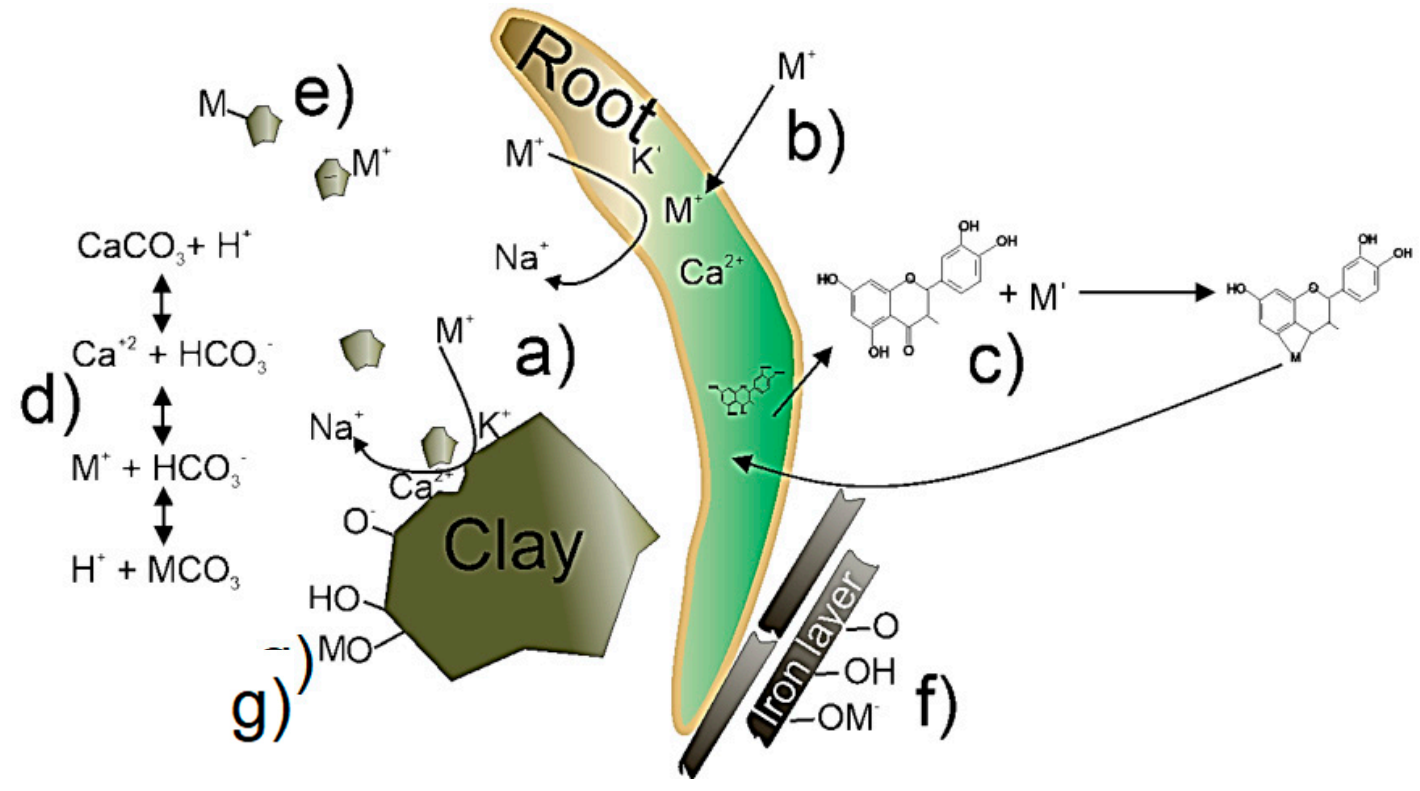

Figure 2. Metal removal mechanisms in constructed wetlands by plant and support material. (a) cation exchange; (b) plant uptake; (c) metal chelation by root exudates; (d) carbonate precipitation;

(e) adsorption to particulate matter; (f) adsorption onto iron layer and (g) adsorption onto clay material.

\subsubsection{Accumulation and Detoxification Mechanisms}

The metal accumulation observed in CW systems plants is the result of the balance between accumulation, detoxification, and adaptability mechanisms. These mechanisms are multigenic and involved (i) biomineralization; (ii) the formation of complexes with glutathione, chelation with metallothioneins and phytochelatins; (iii) hyperactivity of antioxidant plant systems and chelation of heavy metals by root exudates. Biomineralization onto roots, leading to metal precipitation and intracellular biomineralization, e.g., iron plaque formation onto the plants root, has been proven to act as a barrier for metal uptake in plants due to metals affinity for Fe hydroxide (See Figure 2). The iron plaque has been observed in macrophytes like Typha latifolia and Phragmites australis, plants commonly used in CW systems. Intracellular sequestration of minerals occurs through the incorporation of metals in calcium oxalate crystals $(\mathrm{CaOx})$ and calcium carbonates $\left(\mathrm{CaCO}_{3}\right)$. This phenomenon has been reported for $\mathrm{Al}, \mathrm{Pb}, \mathrm{Cd}, \mathrm{Zn}, \mathrm{Mn}$, and $\mathrm{Sr}$ in Ficus retusa, Nicotiana tabacum, and Solanum lycopersicum $[46,59,61,62]$.

The formation of complexes with glutathione, chelation with metallothioneins and phytochelatins and subsequent transport into the vacuole is another mechanism observed. The metal bind to the thiol group contained in these compounds to form a complex, it is a common mechanism that maintain low concentrations of free metals and metalloids in plant cytoplasm and an increase in its production is directly related to the increase of metal exposition [46,63], e.g., this effect was observed for $\mathrm{Pb}$ in C. vulgaris, $\mathrm{Cr}, \mathrm{Zn}, \mathrm{Cd}$, and $\mathrm{Hg}$ in $R$. sativus, $\mathrm{Al}$ in V. radiata [64].

Plants exposed to metals are observed to develop an oxidative stress that is minimized by plants through antioxidant enzymes like catalase, peroxidase, ascorbate peroxidase, among others. Macrophytes such as Alternanthera sp., Eclipta sp., Marselia sp., Typha sp., and Ipomea sp. exposed to heavy metal industrial discharges, have shown a direct correlation of metal accumulation and the hyperactivity of antioxidants like catalase and peroxidase [65]. 
Root exudates secreted by plants can act as chelator of heavy metals. Root exudates includes organic acid fractions that occurs as anions in soils, these substances are associated to detoxification processes by chelating metals and converting them to inactive and non-toxic forms and reducing their intake rate [46,58]. For instance, $\mathrm{Cu}(\mathrm{II})$ as copper sulfate $\left(\mathrm{CuSO}_{4}\right)$ and copper nitrate $\left(\mathrm{Cu}\left(\mathrm{NO}_{3}\right)_{2}\right)$ has been proved to induce the exudation of organic acids in Typha latifolia [66]. Other plants used in phytoremediation such as Poa annua, Medicago polymorpha, and Malva sylvestris showed a correlation between the higher concentrations of $\mathrm{Cd}, \mathrm{Cu}$, and $\mathrm{Zn}$ and the excretion of low molecular organic acids [67].

\subsection{Contributions from Support Material to Metal Removal}

The most common mineral support materials used in CWs for AMD treatment are: limestone, dolomitic limestone, gravel, coarse gravel, sand, sandy-soil, and bentonite. On the other hand, organic support material includes peat, cattle manure, pebbles, good shavings, goat manure, charcoal, and slag $[43,51,53,55,61]$.

The main goal for the use of $\mathrm{CW}$ in the treatment of $\mathrm{AMD}$ is the reduction of the bioavailability of the heavy metals, and the metal removal contributions from support material includes: (1) cation exchange, is a short time retention that occurs when cations are attached to the surfaces of minerals and organic surfaces by electrostatic attraction, sometimes called outersphere complexation; (2) chemisorption, is a long-term immobilization and represents a stronger and permanent bonding compared to cation exchange, this mechanism involves ionic and especially covalent bonding, it is sometimes called innersphere complexation and (3) precipitation and co-precipitation, is an important adsorptive mechanism in support material and wetland sediments; this mechanism is enhanced by the increase of $\mathrm{pH}$ which results from the solubilization of some acid consuming minerals and carbonates formation; this specially occurs when limestone kind support material is dissolved by AMD solution. Limestone reacts with acidity present in the mine drainage to form free calcium $\left(\mathrm{Ca}^{2+}\right)$, dissolved carbon dioxide (carbonic acid, $\mathrm{H}_{2} \mathrm{CO}_{3}$ ) and bicarbonate $\left(\mathrm{HCO}_{3}{ }^{-}\right)$[35,68-70]. Elements such as $\mathrm{Pb}$ and $\mathrm{Cu}$ in general tends to be adsorbed most strongly than elements like $\mathrm{Zn}, \mathrm{Ni}$, and $\mathrm{Cd}$. On the other hand, carbonate precipitation is especially effective for the removal of $\mathrm{Pb}, \mathrm{Ni}$, and $\mathrm{Mn}$ [44].

Generally, in new CW systems it can be observed a period of major efficient removal related to the initial filling of sorption sites on newly submerged clay minerals in the wetland base and buns [54].

Adsorption of metals to particulate matter, originated from the degradation of mineral and organic support material and plants, is also an important mechanism. More than $50 \%$ of the heavy metals can be easily adsorbed onto particulate matter in the wetland, and thus be removed from water by sedimentation [44].

In most of the CW systems for AMD treatment, the principal contaminant of concern is Fe though $\mathrm{Al}, \mathrm{Mn}$, and other metals can also be present in acidic mine waters [54] and are easily removed by increasing the $\mathrm{pH}$ in the system.

The final sink for elements is not usually explained, but Fe is suggested to precipitate as ferric oxide and ferric phosphate [54]. One of the techniques to quantify the "immobilization" of heavy metals in the system involves the use of sequential fractionation extractions which can provide evidence of the element fractionation in the substrate material [71].

Constructed wetland systems for AMD treatment can be amended and fed with organic matter in between the support material since the availability of organic matter (nutrients and carbon) enhances processes such as sulfate reduction promoting the removal of heavy metals such as $\mathrm{Fe}, \mathrm{Cu}, \mathrm{Pb}$, $\mathrm{Zn}$, and Ni [55]. This also provides the substrate or carbon source for anaerobic microorganisms that produces alkalinity [43]. The common organic amendments are wood chips, livestock manure, winery waste, crop residues, organic soil, municipal compost, municipal biosolids, and grain mill by-products [55]. However, a balance between mineral and organic support material need to be maintained since both materials contribute to the filtration of the precipitated forms of metals [55]. 
Some of the principal heavy metal removal mechanisms regarding plants and support material are shown in Figure 2.

\subsection{Role of Microorganisms in CW Treating Acid Mine Drainage Containing Heavy Metals}

Most of the constructed wetlands (CW) studies indicate that microorganisms are the main component of these treatment systems, because they interact more with wastewater, packing medium and vegetation to achieve the removal of contaminants [34,72-75].

Heavy metals removal by microorganisms, in any natural environmental system or open treatment system, could refer to bacteria; microalgae (especially Chlorella genus); bacteriophages and/or protozoa. However, protozoa are highly sensitive to heavy metals presence, including zinc and copper, for that reason they have been used as bioindicators of metal water contaminants [76-78].

Viruses have not presented a significant interaction with heavy metals, possibly due to the capsid protein structure that does not allow it to interact with the external environment. Also, when bacteria are under stress due to heavy metals, viruses have an opportunistic behavior [79].

Respect to microalgae, Chlorella vulgaris is being subject of bioremediation studies because it has shown tolerance and the presence of phytohormones that allow heavy metals accumulation [80,81], such as many other hydrophytes plants [82,83].

Despite this, the most viable option to apply constructed wetlands in mining are the subsurface type because they are more efficient in its operating control parameters such as hydraulic load, organic load, and plant density $[47,84]$. One characteristic of these systems is that residual water is never exposed to the surface and, therefore, they do not receive solar radiation, so microalgae cannot grow despite its ability to accumulate metals. In this sense the removal of heavy metals in constructed wetlands mediated by microorganisms, refers exclusively to the bacterial action and in anaerobic conditions also refers to archaeas [85-87].

Due to the physico-chemical characteristics of AMD such as $\mathrm{pH}$ between 0.5-5.0, sulfate concentration above of $400 \mathrm{mg} / \mathrm{L}$, Eh above of $250 \mathrm{mV}$ and high concentrations of $\mathrm{Fe}, \mathrm{Cu}$ and/or $\mathrm{Zn}$, only acidophilic bacteria or archaea can exist. To respect, [88] describes bacterial genus isolated in various AMD sites and its phenotypes (See Table 3).

Table 3. Genus and phenotype of microorganisms isolated from different mines. Modified of [88,89].

\begin{tabular}{lll}
\multicolumn{1}{c}{ Genus } & \multicolumn{1}{c}{ Phenotype } & \multicolumn{1}{c}{ Mine Water Type } \\
\hline Leptospirillum spp. & iron-oxidizer, mesophile & Tin, Cooper, cooper with $\mathrm{pH} \leq 1.0$ \\
\hline Ferroplasma acidiphillum & iron-reducing heterotroph & Tin, cooper and copper wit $\mathrm{pH} \leq 1.0$ \\
\hline Acidocella spp. & iron-reducing heterotroph & Tin \\
\hline Ferrimicrobium spp. & iron-oxidizing/reducing heterotroph, mesophile & Tin and copper wit $\mathrm{pH} \leq 1.0$ \\
\hline Acidimicrobium ferroxidans & Fe ox./red. Heterotroph, moderate thermophile & Copper with $\mathrm{pH} \leq 1.0$ \\
\hline Ferrovum myxofaciens & iron-oxidizer, psychrotolerant & Copper with $\mathrm{pH} \leq 1.0$ \\
\hline Thiomonas spp. & Iron-and sulfur-oxidizer, moderate acidophile & Coal, tin and copper \\
\hline Halothiobacillus spp. & Iron-and sulfur-oxidizer, moderate acidophile & Tin \\
\hline Acidobacterium-like spp. & $\begin{array}{l}\text { iron-reducing } \\
\text { heterotroph }\end{array}$ & Tin and copper \\
\hline Ferroplasma spp. & $\begin{array}{l}\text { iron-oxidizing/reducing } \\
\text { heterotroph }\end{array}$ & Copper with $\mathrm{pH} \leq 1.0$ \\
\hline
\end{tabular}

\subsubsection{Microorganism Response to Heavy Metals Presence and Other Conditions of AMD}

Perhaps the most known and studied mechanism of heavy metals removal by microorganisms is the reduction of $\mathrm{SO}_{4}{ }^{2-}$, and $\mathrm{SO}$ and subsequent precipitation of inorganic ions mediated by sulfur. This arises from the main known sulfur transformation processes in surface-flow constructed wetlands. 
In anaerobic zones sulfur has been reduced to $\mathrm{H}_{2} \mathrm{~S}$, this acid reacts with heavy metals releasing the hydrogen molecule and forming metal sulphides (e.g., FeS, ZnS) which quickly precipitate. In addition, the lowering of acidity in the system due to bacterial sulphate reduction to sulphide can prompt further precipitation of metals as hydroxides (e.g., $\mathrm{Pb}(\mathrm{OH})_{3}, \mathrm{Cd}(\mathrm{OH})_{2}$ and carbonates (e.g., $\left.\mathrm{MgCO}_{3}\right)[89,90]$. Figure 3 proposes the removal or tolerance mechanisms that exist within a wetland when metal sulphides interact with bacterial cells.

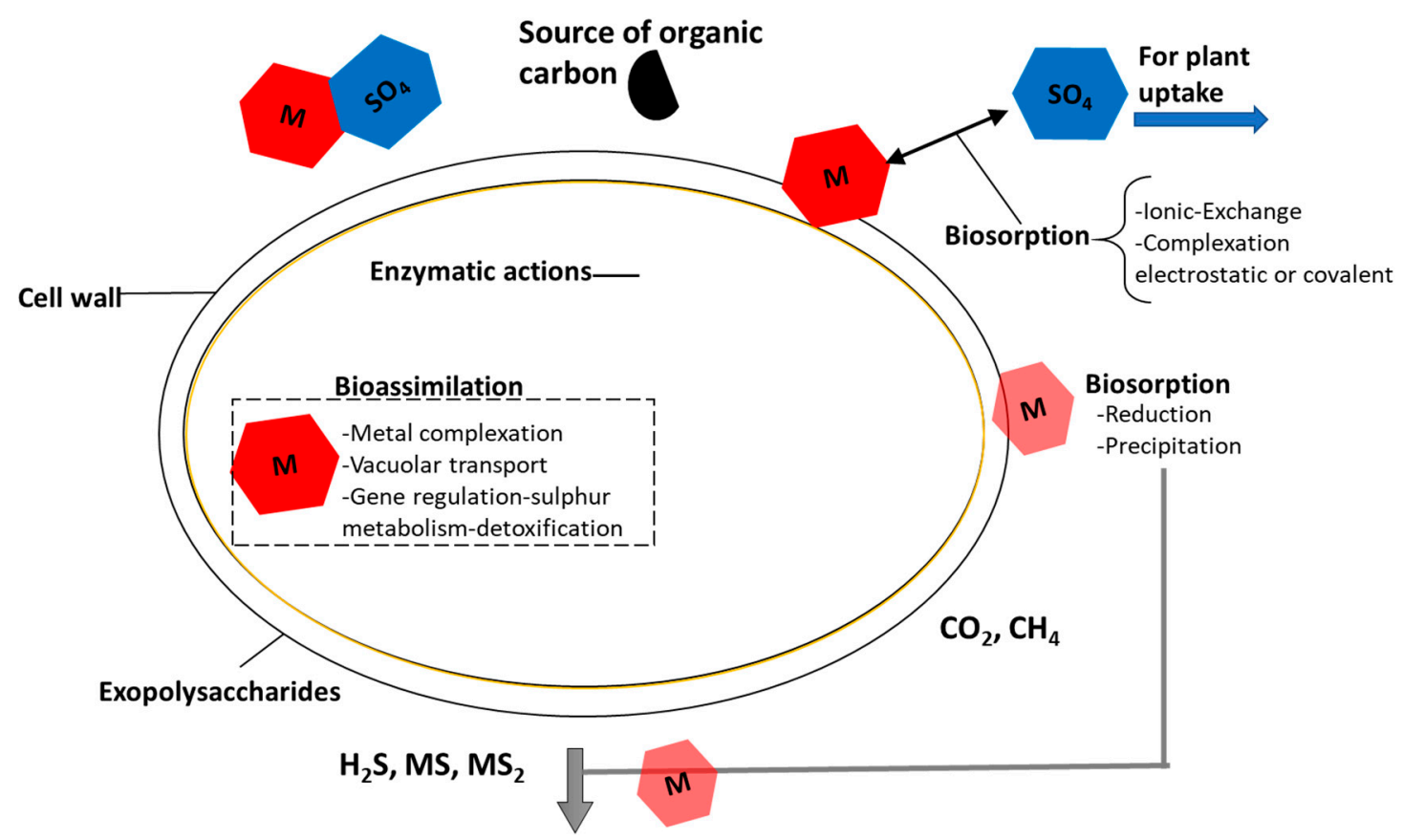

Figure 3. Possible mechanisms of bacteria present in constructed wetlands for the removal, transformation, and tolerance of heavy metals in acid mine drainage (AMD).

In CWs, anaerobic conditions could be propitiated, which are required for sulfatoreduction. However, it is necessary to consider, simultaneously, the operation of all components of CWs in absence of oxygen [91]. For example, sulfatoreduction implies metallic sulphides generation and subsequently its precipitated into the $\mathrm{CW}$ by chemical speciation. This process, in turn, results in clogging which is one of the disadvantages of CW [92-95].

\subsubsection{Plant Growth Promoting Bacterium}

Symbiosis between plants and rhizospheric bacteria could be the most beneficial dynamic population during bioremediation process of ADM in CW systems. In fact, it has been shown that the main factor in plants to accumulate heavy metals is the presence of rhizospheric bacteria, especially when they have developed some mechanism of tolerance towards metals, from symbiosis to synergism $[44,96]$.

Plant growth promoting rhizobacteria (PGPR) is the term for a bacterium that promote photosynthetic organism's growth through compounds secretion such as indoleacetic acid (IAA), abscisic acid (AA) and auxins, besides behaving as hormones for plants, they offer protection from environmental stress of toxic substances [97,98], as heavy metals.

Isolations have been made to obtain PGPR identification in diverse geographic locations, and the following genera have been found, from higher to lower density, Flavobacterium, Kleibsella, Rhizobium, Pseudomonas, Azospitillum, Actinoplanes, Agrobacterium, Azotobacter and Bacillus [64,99,100]. In addition, Ashraf et al. (2017) presents in detail 16 plant species, medium heavy metal contaminants, and identified microbiota [100]. These species do not tolerate the most extreme acidic conditions 
reported in $\mathrm{ADM}$, but they do develop at $\mathrm{pH}$ values above 2.5, so they may be applicable for bioremediation of AMD.

Microorganism development in a biofilm form is one of the main characteristics of $\mathrm{CW}$ in wastewater treatment, which is made up of $15 \%$ bacterial cells and $85 \%$ of cellular matrix [101,102], which is mainly constituted by extracellular polymeric substances (EPS) as polysaccharides and in lower proportion proteins, lipids, and humic acids $[103,104]$. All these organic substances have an adsorbent capacity of heavy metals by surface phenomena such as Van der Waals forces and chemisorption [92,93].

Also, biofilm contains channels within its structure, where water, enzymes and nutrients circulate. Through these channels different bacterial cells species establish symbiotic relationships and dependencies between them. The highlight relationship is communication through chemical signals called quorum sensing (QS) which regulate different gene expression, in distinct parts of bacterial population [94].

In this sense, different bacterial species present in biofilm make an important change in their metabolism, as those related to heavy metals detoxification. These detoxification mechanisms include chemical valence change by oxidation or reduction through specific enzymes. For example, the reduction of $\mathrm{Hg}^{2+}$ to $\mathrm{Hg}^{0}$ by mercuric reductase enzyme allows metal volatilization before aqueous medium is affected. Similar mechanism occurs with $\mathrm{Cr}^{6+}$ when is reduced to $\mathrm{Cr}^{3+}$ through the $\mathrm{ChrR}$ reductase enzyme which is present in Pseudomona putida bacterium [95] as well as oxidases enzymes, which intervene to obtain $\mathrm{As}^{5+}$ from $\mathrm{As}^{3+}$.

It has been reported that bacteria produce polythiol polypeptides in different environments with toxic metals such as $\mathrm{Cd}^{2+}, \mathrm{Ag}, \mathrm{Cu}$, and $\mathrm{Zn}$ and this enzyme allowing an efflux ATPase which keeps low levels of inorganic toxins at intracellular levels $[105,106]$. Also, these organic substances promote the increasing of $\mathrm{pH}$ values.

Most of the heavy metals detoxification mechanisms of tolerance are mediated by mutant species, for example Arthrobacter spp. [107] or Bacillus spp. [108], which have been able to recombine DNA, and therefore incorporate at least one plasmid of some bacterial species that has expressed resistance as Alcaligenes xylosoxydans [109], Arthrobacter spp. [107], and Bacillus spp. [108].

For instance, two large plasmids (pMOL28 and pMOL30) were identified by Diels and Mergeay (1990) through Alcaligenes eutrophus isolation from decantation basin sediments from a zinc smelt factory with physico-chemical characteristics very similar to AMD [109]. The pMOL28 plasmid is resistant to nickel, cobalt, chromate, and mercury and pMOL30 is resistant to cadmium, cobalt, zinc, copper, lead, and mercury. When A. eutrophus species were introduced to contaminated soils with heavy metals it was found that native bacterial strains developed two plasmids with size very similar to those of A.eutrophus, which allowed these native strains to significantly increase their tolerance towards $\mathrm{Cd}, \mathrm{Co}$, and $\mathrm{Zn}$.

On the other hand, Simmons et al. (2008) showed evidence of evolutionary processes which occur over a short time-scale period. DNA sequence obtained from a biofilm developed under acid mine drainage conditions was reconstructed, taking into account the effects of strains' genomic variations. The genetic sequence revealed species variations between Leptospirillum genus, in a short time, related with plasmid/phase-like regions, a variation at the nucleotide level [110].

\subsubsection{Isolated Consortium from Acid Mine Drains}

In addition to the obvious advantages of using AMD bacterial consortia to inoculate CW, such consortia may also have other environmental benefits. In fact, heavy metal-tolerant bacteria have been recently reported with positive changes in environmental systems. Specifically, they increment rates observed in carbon, nitrogen, and phosphorus assimilation. The study performed by Kuppusamy et al. (2016) [111] used heavy metal tolerant bacteria of Trabulsiella genus to remedy contaminated soils with petroleum aromatic hydrocarbons (PAH) [111]. After 90 days, bacteria colonization contributed to reduce the benzo (a) pyrene lifetime from 100 to $50 \mathrm{mg} / \mathrm{L}$ and PAH 
levels were reduced by $80 \%$, suggesting that the aromatic compounds were used as carbon source since volatilization was not viable at the experimental conditions. In addition, nitrogen fixation and phosphorus solubilization were observed and correlated with a considerably increasing vegetation density and a $70 \%$ average reduction of $\mathrm{LD}_{50}$ in soil [111].

Furthermore, Amabilis-Sosa et al. (2015) [96] evaluated chemical oxygen demand (COD) and $\mathrm{NH}_{4}-\mathrm{N}$ removal in subsurface constructed wetlands $(\mathrm{CW})$ which were inoculated with five heavy metal tolerant bacteria strains isolated from Mexico center mining. The experiment was contrasted in real time with a CW system in same construction and operation characteristics as the inoculated ones, but with conventional bacteria (rhizospheres and wastewater).

Experiment was carried out for 156 days and the results indicated that tolerant bacteria $\mathrm{CW}$ exhibited a degradation rate constant of $0.92 \mathrm{~d}^{-1}$, which is significantly higher than conventional bacteria CW $\left(0.73 \mathrm{~d}^{-1}\right)$. Likewise, nitrification rate was $0.63 \mathrm{~d}^{-1}$ in $\mathrm{CW}$ inoculated with heavy metal-tolerant bacteria, while conventional bacteria $\mathrm{CW}$ was $0.38 \mathrm{~d}^{-1}$ [96].

The COD and nitrification removal rates were also higher than several reported in literature $[73,84,112]$. Although there are few studies on removal kinetics changes in organic compounds by heavy metal-tolerant bacteria, those results have been the most forceful.

\section{Implementation of Constructed Wetlands (CW) for Mine Water Remediation: Scaling and Residues Generated}

Since $\mathrm{CW}$ require minimal maintenance and can be applied at remote or at abandoned mine sites where the installation and maintenance of an active system would be difficult, they can be used to attenuate and mitigate the negative impact of AMD.

This technology, which combines naturally-occurring biogeochemical, geochemical, and physical processes, can be used for the long-term remediation of mine water. Depending on the size and design of this type of systems they would require rehabilitation every $5-10$ years but their expected lifespan is around 20 years [113].

Constructed wetlands can also be considered cost-effective processes as long as the process is careful designed and constructed. A staged designed of the wetland system should be considered, as suggested by Wildeman et al. (1993) [114], which includes: (1) laboratory studies, (2) bench-scale studies, (3) pilot-scale systems, and (4) full-scale systems. Each of the stages allows to get important and valuable information that could lead to the development of optimum systems and a successful scaling of the CW system.

It has been reported that passive systems work well at low volume of AMD discharges $\left(<0.45 \mathrm{~m}^{3} / \mathrm{m}^{2} \cdot \mathrm{d}\right)$ containing moderate to high acidity and metals concentration, while they seem to be effective to treat larger flows (up to $11.25 \mathrm{~m}^{3} / \mathrm{m}^{2} \cdot \mathrm{d}$ ) for net alkaline water containing Fe [113].

The design factor is an important aspect to consider before implement the system. Data from literature report that design factors of $3.5 \mathrm{~g}$ acidity $/ \mathrm{m}^{2} \cdot \mathrm{d}$ (for anaerobic wetlands) and $10 \mathrm{~g} \mathrm{Fe} / \mathrm{m}^{2} \cdot \mathrm{d}$ (aerobic and anaerobic wetlands) have been successfully used $[113,115]$, in the case of vertical flow wetlands (VF-CW) a criterion for a long-term acidity removal rate of $35 \mathrm{~g} / \mathrm{m}^{2} \cdot \mathrm{d}$ has been reported [116].

In the United States the first large scale passive aerobic system $\left(8.5 \mathrm{~m}^{3} / \mathrm{m}^{2} \cdot \mathrm{d}\right.$ capacity) was built in 1992 by Tennessee Valley Authority in Alabama; and the West Fork Unit system $\left(5.11 \mathrm{~m}^{3} / \mathrm{m}^{2} \cdot \mathrm{d}\right.$ capacity) was the first large-scale anaerobic biotreatment system constructed in Missouri in 1996 built by Asarco Company for its underground lead mine.

In UK, passive treatment technology was implemented in the 1990s and recommended for the long-term remediation of mine waters such as acidic spoil heap leachate, deep mine drainage, spoil leachate, drift mine water, etc., wherever land availability is not unduly limiting [117]. Constructed wetland systems are reported as the most widely used passive mine water treatment technology for polluted mine waters [27].

There are some general established considerations to conduct the treatment, for example, if $\mathrm{Fe}$, $\mathrm{Mn}$ and $\mathrm{Al}$ are the only contaminants of concern, the guiding principle is to neutralize the mine water 
using sulfate reduction and/or carbonate dissolution, and then use aerobic processes to strip the remaining metals from solution.

In cases where more toxic metals are present in the mine water, metal interactions and speciation, that could lead to the formation of toxic compounds, has to be considered [27].

In 2005, Skousen and Ziemkiewicz evaluated 116 systems comprised of eight system types treating AMD in eight states in the eastern of United States, and four years after 14 sites were re-evaluated for their performance [118]. Results from this study demonstrated that most of the passive systems were effective for more than five years. Regarding aerobic wetlands their results showed that those systems removed between 0.1 and $27 \mathrm{t}$ of acid/year at costs ranging from $\$ 23$ to $>\$ 7000 / t /$ year over the expected 20-year lifetime. The anaerobic wetlands showed wide variation in acid removal (0 to $67.9 \mathrm{t} /$ year of acid load treated $\left(47.6 \mathrm{~g} / \mathrm{m}^{2} \cdot \mathrm{d}\right)$ ) and varied in treatment costs from $\$ 341 / \mathrm{t} /$ year to $\$ 4762 / \mathrm{t} /$ year. From this study authors also found that anaerobic wetlands were fairly robust systems that work well if not overwhelmed with acid or metal loads. The vertical flow wetlands (VF-CW) had removal efficiencies well above the design standards and iron was found to be the key element of concern, which causes systems to fail due to armoring or floc buildup.

Nowadays, it is considered that passive systems have substantially reduced water treatment costs at many mine sites due to its low capital, maintenance, and operating costs as compared to active systems.

A variety of factors affect the cost of constructed wetlands, such as: detention time, treatment goals, media type, pretreatment type, number of cells, source and availability of gravel media, and terrain [119].

The construction cost of a system can be roughly calculated based on accepted standard rates for building passive systems. These rates can vary and it is zone-dependent, data from 2005 established costs of $\$ 3.25 / \mathrm{m}^{3}$ for excavation, $\$ 27 / \mathrm{t}$ of limestone, $\$ 27 / \mathrm{t}$ of slag, $\$ 27 / \mathrm{m}^{3}$ of organic matter, costs for plants about $\$ 0.50-1.00$ per plant in the United States $[118,119]$. To the rates mentioned before other costs need to be considered related to the design and specific requirements of the wetland system. For example, the average wetland installation cost for a subsurface flow wetland treating wastewater is $\$ 215,000 / \mathrm{ha}$, while the average cost for a surface flow wetland is $\$ 54,500 / \mathrm{ha}$ [119]. In developing countries and areas where land is available price can be lower than the cited above.

How long can a CW be operated? The accepted lifespan for passive system designs is 20 years [118], after that CWs would require to be dismantled and residues associated with the treatment must be properly disposed. Particularly in the case of mine water treatment, the fate of the toxic metals has to be monitored. Metals can undergo different transformations by means of processes such as oxidation-reduction, adsorption-desorption, complexation, etc. Therefore, the CW elements such as plants, soil, and media (rock, gravel, etc.) have to be analyzed for metal content and the long-term stabilities of residues need to be tested and evaluated to determine whether they will need to be removed or if special precautions are necessary for final storage. For example, a particular problem arising from the disposal of treatment residues generated by removal of arsenic is that arsenic can be highly mobile and has the potential to leach back to ground and surface waters [120].

The study conducted by Swash and Monhemius [121] focused on analyzing the solubility of residues formed during the effluent treatment of an acidic ( $\mathrm{pH} 3$ to 4) mine discharge enriched in iron $(<100 \mathrm{mg} / \mathrm{L})$, zinc $(<80 \mathrm{mg} / \mathrm{L})$, manganese $(<20 \mathrm{mg} / \mathrm{L})$, and arsenic $(<2 \mathrm{mg} / \mathrm{L})$ at the Wheal Jane constructed wetland facility in Cornwall, UK. Their results demonstrated that in the aerobic cells, the iron was precipitated as an amorphous (poorly crystalline goethite and ferrihydrite), orange-brown material, usually referred to as ochre, onto which arsenic $(>0.1 \%)$ and trace amounts of base metals were adsorbed. Thus such residues have to be classified as hazardous waste according to UK landfill regulations. On the other hand, the anaerobic samples were composed mostly of carbonaceous material onto which inorganic elements were adsorbed or had precipitated. They were found to contain minimal amounts of toxic compounds and were considered to be less of a disposal problem [121]. 
Some studies recommend the harvest of plant material following by its transformation into methane (in anaerobic conditions) or to be used as compost or green fertilizers as the example of polyculture constructed wetland (PCW) designed to the phytoremediation of B mine effluents in field conditions [51].

Other suggested treatments include dewatering, densification, and solidification of the sludges as a prerequisite prior to landfilling to minimize any subsequent settling/subsidence of the landfill site, or solidification using cement or conversion to bricks as final disposal/recycling options.

Solidification/stabilization (S/S) is a feasible management method which includes a range of processes, normally used as a pre-landfill waste treatment that aims to make hazardous wastes safe for disposal [122].

Residues containing a high percentage of carbonaceous material can be disposed of separately, or incorporated into bricks, or dried and burnt to recover the contained metals $(\mathrm{Zn}, \mathrm{Pb}, \mathrm{Cu}$, and $\mathrm{Cd})$.

The caution of removal and disposal of the residual wastes from the site has to be considered from environmental, health, and cost effects since the costs associated to AMD treatment are much lower than undesirable effects.

\section{Concluding Remarks}

From all constructed wetlands arrangements sub-surface flow systems have been proven to be the most efficient systems for AMD treatment, mainly by promoting the complete interaction of water with support material and plant roots, and by providing anaerobic conditions that leads heavy metal removal by adsorption and precipitation mechanisms. The metal removal mechanisms are usually attributed to a particular CW component: (i) the support material (mineral and/or organic), which contributes to the removal mainly by adsorption processes, (ii) plants (emerging, floating and submerged) that contribute mainly by direct uptake mechanisms and (iii) microorganisms (bacteria and archaea) which contribute by promoting reduction and subsequent precipitation of metals. However, the removal of heavy metals from aqueous solution comes from an interaction and synergetic effect between them. From all CW components microorganisms are the most interactive ones. Specifically, microorganism-plant interactions play a crucial role on heavy metal removal, principally by the symbiosis that promotes plant growth and heavy metal tolerance mechanisms. Additionally, the formation of litter and biofilm layers as a result of natural CW processes, contributes trapping metals trough adsorption by organic surface groups at advanced stages of system operation.

Strategies for the improvement of heavy metal removal, includes the amendment of organic matter in between the mineral support material to increase heavy metal removal, principally by promoting plant growth, microorganism's establishment, and by trapping heavy metals. Inoculation of AMD with specialized bacterial consortiums into the $\mathrm{CW}$ systems also increase heavy metal removal, since most of heavy metals detoxification are mediated by mutant species that express resistance, and increase nitrogen, carbon, and phosphate fixation that subsequently promotes vegetation development. Additional recommendations include a careful vegetation selection and take into account seasonal effects on system operation.

The principal limitations for CW treating AMD is the toxicity effect that heavy metals produce on CW plants and microorganisms. However, these aspects can be solved partially by choosing careful constructed wetlands components suitable to the AMD characteristics. From the economic point of view, a variety of factors affect the cost of constructed wetlands, such as: detention time, treatment goals, media type, pretreatment type, number of cells, source and availability of gravel media, and land requirements, among others. To solve equilibria between systems requirements and costs, an experimental model must include: (1) laboratory studies, (2) bench-scale studies, (3) pilot-scale systems, and (4) full-scale systems. Each of the stages allows to get important and valuable information that could lead to the development of optimum systems and a successful scaling of the CW system. Depending on the size and design of this type of systems they would require rehabilitation every 5-10 years but their expected lifespan is around 20 years. Another important issue is the disposal of 
the residual waste produced by the system at the end of the operation. In general, the use of residual waste as a construction material is suggested. The caution of removal and disposal of the residual wastes from the site has to be considered from environmental, health, and cost effects, since the costs associated with AMD treatment are much lower than undesirable effects.

Author Contributions: A.M.P.-E. wrote, reviewed and edited Sections 1, 2 and 4. R.L.P. wrote-reviewed and edited Sections 3 and 5. L.E.A.S. conceived, wrote, reviewed and edited Sections 2 and 3, and also helped with Section 4. G.V. and G.G. wrote Sections 1 and 2.

Funding: This work was supported by CONICYT/FONDAP/15130015, Problemas Nacionales ID1520 from CONACYT and PAPIIT IN204918.

Conflicts of Interest: The authors declare no conflict of interest.

\section{References}

1. Skousen, J.; Sexstone, A.; Ziemkiewicz, P. Acid mine drainage control and treatment. In Reclamation of Drastically Disturbed Lands; West Virginia University: Morgantown, WV, USA, 2000.

2. Akcil, A.; Koldas, S. Acid Mine Drainage (AMD): Causes, treatment and case studies. J. Clean. Prod. 2006, 14, 1139-1145. [CrossRef]

3. Johnson, D.B. Chemical and microbiological characteristics of mineral spoils and drainage waters at abandoned coal and metal mines. Wat Air Soil Pollut. Focus 2003, 3, 47-66. [CrossRef]

4. Dold, B. Aguas Ácidas: Formación, predicción, control y prevención. Rev. Miner. 2003, 309, $29-37$.

5. Strosnider, W.; Llanos, F.; Marcillo, C.; Callapa, R.; Nairn, R. Impact on tributaries of the Pilcomayo River by additional pollutants from mine acid drainage from Cerro Rico de Potosí-Bolivia. Adv. Sci. Eng. 2014, 5, 1-17.

6. Calabrese, E.J.; Kostecki, P.T.; Dragun, J. Contaminated Soils, Sediments and Water Volume 10: Successes and Challenges; Springer Science \& Business Media: Berlin, Germany, 2006; ISBN 978-0-387-28324.

7. Hutchinson, I.P.G.; Ellison, R.D. Mine Waste Management; International Atomic Energy Agency: Vienna, Austria, 1992.

8. USEPA Technical Document: Acid Mine Drainage Prediction 1994. Available online: http:/ /www.epa.gov/ sites / production/file/2015-09/documents/amd.pdf (accessed on 13 September 2018).

9. Blowes, D.W.; Ptacek, C.J.; Jambor, J.L.; Weisener, C.G. The geochemistry of acid mine drainage. Treatise Geochem. 2003, 9, 612.

10. ITRC. Biochemical Reactors for Treating Mining-Influenced Water. BCR-1; Interstate Technology \& Regulatory Council, Biochemical Reactors for Mining-Influenced Waste Team: Washington, DC, USA, 2013.

11. Lopes, I.; Gonçalves, F.; Soares, A.; Ribeiro, R. Ecotoxicological tools in the remediation of acid mine drainage. Toxicol. Environ. Chem. 1999, 70, 441-460. [CrossRef]

12. Rügner, H.; Finkel, M.; Kaschl, A.; Bittens, M. Application of monitored natural attenuation in contaminated land management-A review and recommended approach for Europe. Environ. Sci. Policy 2006, 9, 568-576. [CrossRef]

13. Yim, J.; Kim, K.; Kim, S. Effect of hardness on acute toxicity of metal mixtures using Daphnia magna: Prediction of acid mine drainage toxicity. J. Hazard. Mater. B 2006, 138, 16-21. [CrossRef] [PubMed]

14. Xavier, C.; Chamorro, S.; Vidal, G. Chronic effects of Kraft mill effluents and endocrine active chemical on Daphnia magna. Bull. Environ. Contam. Toxicol. 2005, 75, 670-676. [CrossRef] [PubMed]

15. Chamorro, S.; López, D.; Brito, P.; Jarpa, P.; Piña, B.; Vidal, G. Sublethal effects of chlorine-free kraft mill effluents on Daphnia magna. Bull. Environ. Contam. Toxicol. 2016, 97, 843-847. [CrossRef] [PubMed]

16. Khan, F.; Kennaway, G.; Croteau, M.; Dybowska, A.; Smith, B.; Nogueira, A.; Rainbow, P.; Luoma, S.; Valsami-Jones, E. In vivo retention of ingested Au NPs by Daphnia magna: No evidence for trans-epithelial alimentary uptake. Chemosphere 2014, 100, 97-104. [CrossRef] [PubMed]

17. Allen, I.; Calow, P.; Baird, D. A mechanistic model of contaminant-induced feeding inhibition in Daphnia magna. Environ. Toxicol. Chem. 1995, 14, 1625-1630. [CrossRef]

18. Yang, Y.; Wei, X.; Lu, J.; You, J.; Wang, W.; Shi, R. Lead-induced phytotoxicity mechanism involved in seed germination and seedling growth of wheat (Triticum aestivum L.). Ecotoxicol. Environ. Safe 2010, 73, 1982-1987. [CrossRef] [PubMed] 
19. Mahmood, T.; Islam, K.; Muhammad, S. Toxic effects of heavy metals on early growth and tolerance of cereal crops. Pak. J. Bot. 2007, 39, 451-462.

20. Bagur-González, M.; Estepa-Molina, C.; Martín-Peinado, F.; Morales-Ruano, S. Toxicity assessment using Lactuca sativa L. bioassay of the metal(loid)s $\mathrm{As}, \mathrm{Cu}, \mathrm{Mn}, \mathrm{Pb}$ and $\mathrm{Zn}$ in soluble in water saturated soil extracts from an abandoned mining site. J. Soil Sediment 2011, 11, 281-289. [CrossRef]

21. Chamorro, S.; Barata, C.; Piña, B.; Casado, M.; Schwarz, A.; Sáez, K.; Vidal, G. Toxicological analysis of acid mine drainage by water quality and land use bioassays. Mine Water Environ. 2018, 37, 88-97. [CrossRef]

22. Biehler, D.; Falck, W. Simulation of the effects of geochemical reactions on groundwater quality during planned flooding of the Königstein uranium mine, Saxony, Germany. Hydrogeol. J. 1999, 7, 284-293. [CrossRef]

23. Nordstrom, D.; Alpers, C.; Ptacek, C.; Blowes, D. Negative $\mathrm{pH}$ and extremely acid mine waters from Iron Montain, California. Environ. Sci. Technol. 2000, 34, 254-258. [CrossRef]

24. Eary, L.; Runnells, D.; Esposito, K. Geochemical controls on ground water composition at the cripple creek mining district, Cripple Creek, Colorado. Appl. Geochem. 2003, 18, 1-24. [CrossRef]

25. Kimura, S.; Bryan, C.; Hallberg, K.; Johnson, D. Biodiversity and geochemistry of an extremely acidic, low temperature subterranean environment sustained by chemolithotrophy. Environ. Microbiol. 2011, 13, 2092-2104. [CrossRef] [PubMed]

26. Williams, M. Arsenic in mine waters: An international study. Environ. Geol. 2001, 267-278. [CrossRef]

27. Younger, P.L.; Banwart, S.A.; Hedin, R.S. Passive Treatment of Polluted Mine Waters. In Mine Water; Environmental Pollution; Springer: Dordrecht, The Netherlands, 2002; pp. 311-396, ISBN 978-1-4020-0138-3.

28. Johnson, D.B.; Hallberg, K.B. Acid mine drainage remediation options: A review. Sci. Total Environ. 2005, 338, 3-14. [CrossRef] [PubMed]

29. Kalin, M. Passive mine water treatment: The correct approach? Ecol. Eng. 2004, 22, 299-304. [CrossRef]

30. Johnson, D.; Hallberg, K. Pitfalls of passive mine water treatment. Rev. Environ. Sci. Biotechnol 2002, 1, 335-343. [CrossRef]

31. Mine Environment Neutral Drainage, (MEND). Review of Passive Systems for Treatment of Acid Mine Drainage; MEND Report 3.14.1; MEND Program: Toronto, ON, Canada, 1999.

32. US EPA, Constructed Wetlands. Available online: https://www.epa.gov/wetlands/constructed-wetlands (accessed on 13 March 2018).

33. Reed, S.C.; Brown, D.S. Constructed wetland design-The first generation. Water Environ. Res. 1992, 64, 776-781. [CrossRef]

34. Vymazal, J.; Kröpfelová, L. Wastewater Treatment in Constructed Wetlands with Horizontal Sub-Surface Flow; Springer Science \& Business Media: Berlin, Germany, 2008; ISBN 978-1-4020-8580-2.

35. Sheoran, A.S. Management of acidic mine waste water by constructed wetland treatment system: A bench scale study. Eur. J. Sustain. Dev. 2017, 6, 245-255. [CrossRef]

36. Sheoran, A.S.; Sheoran, V. Heavy metal removal mechanism of acid mine drainage in wetlands: A critical review. Miner. Eng. 2006, 19, 105-116. [CrossRef]

37. Sheridan, C.; Akcil, A.; Kappelmeyer, U.; Moodley, I. A Review on the Use of Constructed Wetlands for the Treatment of Acid Mine Drainage. In Constructed Wetlands for Industrial Wastewater Treatment; Wiley-Blackwell: Hoboken, NJ, USA, 2018; pp. 249-262, ISBN 978-1-119-26837-6.

38. Nyquist, J.; Greger, M. A field study of constructed wetlands for preventing and treating acid mine drainage. Ecol. Eng. 2009, 35, 630-642. [CrossRef]

39. Woulds, C.; Ngwenya, B.T. Geochemical processes governing the performance of a constructed wetland treating acid mine drainage, Central Scotland. Appl. Geochem. 2004, 19, 1773-1783. [CrossRef]

40. Karathanasis, A.D.; Johnson, C.M. Metal removal potential by three aquatic plants in an acid mine drainage wetland. Mine Water Environ. 2003, 22, 22-30. [CrossRef]

41. Türker, O.C.; Böcük, H.; Yakar, A. The phytoremediation ability of a polyculture constructed wetland to treat boron from mine effluent. J. Hazard. Mater. 2013, 252, 132-141. [CrossRef] [PubMed]

42. Younger, P.L.; Henderson, R. Synergistic wetland treatment of sewage and mine water: Pollutant removal performance of the first full-scale system. Water Res. 2014, 55, 74-82. [CrossRef] [PubMed]

43. Dufresne, K.; Neculita, C.M.; Brisson, J.; Genty, T. Metal retention mechanisms in pilot-scale constructed wetlands receiving acid mine drainage. In Proceedings of the 10th ICARD (International Conference on Acid Rock Drainage)-IMWA (International Mine Water Association), Santiago, Chile, 21-24 April 2015. 
44. Stottmeister, U.; Buddhawong, S.; Kuschk, P.; Wiessner, A.; Mattusch, J. Constructed wetlands and their performance for treatment of water contaminated with arsenic and heavy metals. In Soil and Water Pollution Monitoring, Protection and Remediation; Springer: Berlin, Germany, 2006; pp. 417-432.

45. Mitsch, W.J.; Wise, K.M. Water quality, fate of metals, and predictive model validation of a constructed wetland treating acid mine drainage. Water Res. 1998, 32, 1888-1900. [CrossRef]

46. Marchand, L.; Mench, M.; Jacob, D.L.; Otte, M.L. Metal and metalloid removal in constructed wetlands, with emphasis on the importance of plants and standardized measurements: A review. Environ. Pollut. 2010, 158, 3447-3461. [CrossRef] [PubMed]

47. Leung, H.M.; Duzgoren-Aydin, N.S.; Au, C.K.; Krupanidhi, S.; Fung, K.Y.; Cheung, K.C.; Wong, Y.K.; Peng, X.L.; Ye, Z.H.; Yung, K.K.L.; et al. Monitoring and assessment of heavy metal contamination in a constructed wetland in Shaoguan (Guangdong Province, China): Bioaccumulation of $\mathrm{Pb}, \mathrm{Zn}, \mathrm{Cu}$ and $\mathrm{Cd}$ in aquatic and terrestrial components. Environ. Sci. Pollut. Res. Int. 2017, 24, 9079-9088. [CrossRef] [PubMed]

48. Zhang, T.; Gannon, S.M.; Nevin, K.P.; Franks, A.E.; Lovley, D.R. Stimulating the anaerobic degradation of aromatic hydrocarbons in contaminated sediments by providing an electrode as the electron acceptor. Environ. Microbiol. 2010, 12, 1011-1020. [CrossRef] [PubMed]

49. Sarma, H. Metal hyperaccumulation in plants: A review focusing on phytoremediation technology. J Environ. Sci. Technol. 2011, 4, 118-138. [CrossRef]

50. Ali, H.; Khan, E.; Sajad, M.A. Phytoremediation of heavy metals-Concepts and applications. Chemosphere 2013, 91, 869-881. [CrossRef] [PubMed]

51. Girdhar, M.; Sharma, N.R.; Rehman, H.; Kumar, A.; Mohan, A. Comparative assessment for hyperaccumulatory and phytoremediation capability of three wild weeds. 3 Biotech 2014, 4, 579-589. [CrossRef] [PubMed]

52. Sheridan, G.; Harding, K.; Koller, E.; Pretto, A.D. A comparison of charcoal- and slag-based constructed wetlands for acid mine drainage remediation. Water SA 2013, 39, 369-374. [CrossRef]

53. Batty, L.C.; Younger, P.L. Growth of Phragmites australis (Cav.) Trin ex. Steudel in mine water treatment wetlands: Effects of metal and nutrient uptake. Environ. Pollut. 2004, 132, 85-93. [CrossRef] [PubMed]

54. Stein, O.R.; Borden-Stewart, D.; Hook, P.; Jones, W. Seasonal influence on sulfate reduction and zinc sequestration in subsurface treatment wetlands. Water Res. 2007, 41, 3440-3448. [CrossRef] [PubMed]

55. Brisson, J.; Chazarenc, F. Maximizing pollutant removal in constructed wetlands: Should we pay more attention to macrophyte species selection? Sci. Total Environ. 2009, 13, 3923-3930. [CrossRef] [PubMed]

56. Chen, Y.; Wen, Y.; Zhou, Q.; Huang, J.; Vymazal, J.; Kuschk, P. Sulfate removal and sulfur transformation in constructed wetlands: The roles of filling material and plant biomass. Water Res. 2016, 102, 572-581. [CrossRef] [PubMed]

57. Oertli, J.J.; Grgurevic, E. Effect of pH on the Absorption of Boron by Excised Barley Roots. Agron. J. 1975, 67, 278-280. [CrossRef]

58. Dhir, B.; Sharmila, P.; Saradhi, P.P. Potential of aquatic macrophytes for removing contaminants from the environment. Crit. Rev. Environ. Sci. Technol. 2009, 39, 754-781. [CrossRef]

59. Fleming, E.J.; Cetinić, I.; Chan, C.S.; Whitney King, D.; Emerson, D. Ecological succession among iron-oxidizing bacteria. ISME J. 2014, 8, 804-815. [CrossRef] [PubMed]

60. Yeh, T. Removal of metals in constructed wetlands: Review. Pract. Period. Hazard. Toxic Radioact. Waste Manage 2008, 12, 96-101. [CrossRef]

61. He, H.; Veneklaas, E.J.; Kuo, J.; Lambers, H. Physiological and ecological significance of biomineralization in plants. Trends Plant Sci. 2014, 19, 166-174. [CrossRef] [PubMed]

62. Tripathi, R.D.; Tripathi, P.; Dwivedi, S.; Kumar, A.; Mishra, A.; Chauhan, P.S.; Norton, G.J.; Nautiyal, C.S. Roles for root iron plaque in sequestration and uptake of heavy metals and metalloids in aquatic and wetland plants. Metallomics 2014, 6, 1789-1800. [CrossRef] [PubMed]

63. Rubino, F.M. Toxicity of glutathione-binding metals: A review of targets and mechanisms. Toxics 2015, 3, 20-62. [CrossRef] [PubMed]

64. Ahmed, M.J.K.; Ahmaruzzaman, M. A review on potential usage of industrial waste materials for binding heavy metal ions from aqueous solutions. J. Water Process Eng. 2016, 10, 39-47. [CrossRef]

65. Nayek, S.; Gupta, S.; Saha, R. Effects of metal stress on biochemical response of some aquatic macrophytes growing along an industrial waste discharge channel. J. Plant Interact. 2010, 5, 91-99. [CrossRef] 
66. Lyubenova, L.; Kuhn, A.J.; Höltkemeier, A.; Schröder, P. Root exudation pattern of Typha latifolia L. plants after copper exposure. Plant Soil 2013, 370, 187-195. [CrossRef]

67. Montiel-Rozas, M.M.; Madejón, E.; Madejón, P. Effect of heavy metals and organic matter on root exudates (low molecular weight organic acids) of herbaceous species: An assessment in sand and soil conditions under different levels of contamination. Environ. Pollut. 2016, 216, 273-281. [CrossRef] [PubMed]

68. Brodie, G.A.; Britt, C.R.; Tomaszewski, T.M.; Taylor, H.N. Anoxic Limestone Drains to Enhance Performance of Aerobic Acid Drainage Treatment Wetlands the Tennessee Valley Authority; CRC Press: Boca Raton, FL, USA, 1992.

69. Bai, J.; Yang, Z.; Cui, B.; Gao, H.; Ding, Q. Some heavy metals distribution in wetland soils under different land use types along a typical plateau lake, China. Soil Tillage Res. 2010, 106, 344-348. [CrossRef]

70. Than, K. Principles of Soil Chemistry, 4th ed.; CRC Press, Taylor \& Francis Group: Boca Raton, FL, USA, 2011.

71. Tessier, A.; Campbell, P.G.C.; Bisson, M. Sequential extraction procedure for the speciation of particulate trace metals. Anal. Chem. 1979, 51, 844-851. [CrossRef]

72. Li, Y.; Zhu, G.; Ng, W.J.; Tan, S.K. A review on removing pharmaceutical contaminants from wastewater by constructed wetlands: Design, performance and mechanism. Sci. Total Environ. 2014, 468-469, 908-932. [CrossRef] [PubMed]

73. Adrados, B.; Sánchez, O.; Arias, C.A.; Becares, E.; Garrido, L.; Mas, J.; Brix, H.; Morató, J. Microbial communities from different types of natural wastewater treatment systems: Vertical and horizontal flow constructed wetlands and biofilters. Water Res. 2014, 55, 304-312. [CrossRef] [PubMed]

74. Wu, S.; Kuschk, P.; Brix, H.; Vymazal, J.; Dong, R. Development of constructed wetlands in performance intensifications for wastewater treatment: A nitrogen and organic matter targeted review. Water Res. 2014, 57, 40-55. [CrossRef] [PubMed]

75. Haydar, S.; Haider, H.; Nadeem, O.; Hussain, G.; Zahra, S. Proposed model for wastewater treatment in Lahore using constructed wetlands. J. Fac. Eng. Technol. 2015, 22, 9-19.

76. Martín-González, A.; Borniquel, S.; Díaz, S.; Ortega, R.; Gutiérrez, J.C. Ultrastructural alterations in ciliated protozoa under heavy metal exposure. Cell Biol. Int. 2005, 29, 119-126. [CrossRef] [PubMed]

77. Amaro, F.; Turkewitz, A.P.; Martín-González, A.; Gutiérrez, J.-C. Whole-cell biosensors for detection of heavy metal ions in environmental samples based on metallothionein promoters from Tetrahymena thermophila. Microb. Biotechnol. 2011, 4, 513-522. [CrossRef] [PubMed]

78. Kamika, I.; Momba, M.N.B. Assessing the resistance and bioremediation ability of selected bacterial and protozoan species to heavy metals in metal-rich industrial wastewater. BMC Microbiol. 2013, 13, 28. [CrossRef] [PubMed]

79. Motlagh, A.M.; Bhattacharjee, A.S.; Goel, R. Microbiological study of bacteriophage induction in the presence of chemical stress factors in enhanced biological phosphorus removal (EBPR). Water Res. 2015, 81, 1-14. [CrossRef] [PubMed]

80. Piotrowska-Niczyporuk, A.; Bajguz, A.; Zambrzycka, E.; Godlewska-Żyłkiewicz, B. Phytohormones as regulators of heavy metal biosorption and toxicity in green alga Chlorella vulgaris (Chlorophyceae). Plant Physiol. Biochem. 2012, 52, 52-65. [CrossRef] [PubMed]

81. Ouyang, H.; Kong, X.; He, W.; Qin, N.; He, Q.; Wang, Y.; Wang, R.; Xu, F. Effects of five heavy metals at sub-lethal concentrations on the growth and photosynthesis of Chlorella vulgaris. Chin. Sci. Bull. 2012, 57, 3363-3370. [CrossRef]

82. Kumari, A.; Lal, B.; Rai, U.N. Assessment of native plant species for phytoremediation of heavy metals growing in the vicinity of NTPC sites, Kahalgaon, India. Int. J. Phytoremediation 2016, 18, 592-597. [CrossRef] [PubMed]

83. Thakur, S.; Singh, L.; Wahid, Z.A.; Siddiqui, M.F.; Atnaw, S.M.; Din, M.F.M. Plant-driven removal of heavy metals from soil: Uptake, translocation, tolerance mechanism, challenges, and future perspectives. Environ. Monit. Assess. 2016, 188, 206. [CrossRef] [PubMed]

84. Wu, H.; Fan, J.; Zhang, J.; Ngo, H.H.; Guo, W.; Hu, Z.; Liang, S. Decentralized domestic wastewater treatment using intermittently aerated vertical flow constructed wetlands: Impact of influent strengths. Bioresour. Technol. 2015, 176, 163-168. [CrossRef] [PubMed]

85. Li, X.; Xu, H.; Chen, Z.-S.; Chen, G. Biosynthesis of Nanoparticles by Microorganisms and Their Applications. J. Nanomater. 2011, 2011, 1-16. [CrossRef]

86. Hafeznezami, S.; Kim, J.L.; Redman, J. Redman Jeremy Evaluating Removal Efficiency of Heavy Metals in Constructed Wetlands. J. Environ. Eng. 2012, 138, 475-482. [CrossRef] 
87. Moreau, J.W.; Fournelle, J.H.; Banfield, J.F. Quantifying Heavy Metals Sequestration by Sulfate-Reducing Bacteria in an Acid Mine Drainage-Contaminated Natural Wetland. Front. Microbiol. 2013, 4, 43. [CrossRef] [PubMed]

88. Hallberg, K.B.; González-Toril, E.; Johnson, D.B. Acidithiobacillus ferrivorans, sp. nov.; facultatively anaerobic, psychrotolerant iron-, and sulfur-oxidizing acidophiles isolated from metal mine-impacted environments. Extremophiles 2010, 14, 9-19. [CrossRef] [PubMed]

89. White, C.; Gadd, G.M. An internal sedimentation bioreactor for laboratory-scale removal of toxic metals from soil leachates using biogenic sulphide precipitation. J. Ind. Microbiol. Biotechnol. 1997, 18, 414-421. [CrossRef]

90. Wu, S.; Kuschk, P.; Wiessner, A.; Müller, J.; Saad, R.A.B.; Dong, R. Sulphur transformations in constructed wetlands for wastewater treatment: A review. Ecol. Eng. 2013, 52, 278-289. [CrossRef]

91. Vymazal, J. Plants used in constructed wetlands with horizontal subsurface flow: A review. Hydrobiologia 2011, 674, 133-156. [CrossRef]

92. Piccirillo, C.; Pereira, S.I.A.; Marques, A.P.G.C.; Pullar, R.C.; Tobaldi, D.M.; Pintado, M.E.; Castro, P.M.L. Bacteria immobilisation on hydroxyapatite surface for heavy metals removal. J. Environ. Manag. 2013, 121, 87-95. [CrossRef] [PubMed]

93. Wang, J.; Li, Q.; Li, M.-M.; Chen, T.-H.; Zhou, Y.-F.; Yue, Z.-B. Competitive adsorption of heavy metal by extracellular polymeric substances (EPS) extracted from sulfate reducing bacteria. Bioresour. Technol. 2014, 163, 374-376. [CrossRef] [PubMed]

94. Ding, Y.; Lyu, T.; Bai, S.; Li, Z.; Ding, H.; You, S.; Xie, Q. Effect of multilayer substrate configuration in horizontal subsurface flow constructed wetlands: Assessment of treatment performance, biofilm development, and solids accumulation. Environ. Sci. Pollut. Res. Int. 2018, 25, 1883-1891. [CrossRef] [PubMed]

95. Ramírez-Díaz, M.I.; Riveros-Rosas, H.; Campos-García, J. Reducción bacteriana de cromo hexavalente: Mecanismos y aplicaciones. Rev. Educ. Bioquím. 2009, 28, 73-79.

96. Amabilis-Sosa, L.E.; Siebe, C.; Moeller-Chávez, G.; Durán-Domínguez-de-Bazúa, M.D.C. Accumulation and distribution of lead and chromium in laboratory-scale constructed wetlands inoculated with metal-tolerant bacteria. Int. J. Phytoremediation 2015, 17, 1090-1096. [CrossRef] [PubMed]

97. Patten, C.L.; Glick, B.R. Regulation of indoleacetic acid production in Pseudomonas putida GR12-2 by tryptophan and the stationary-phase sigma factor RpoS. Can. J. Microbiol. 2002, 48, 635-642. [CrossRef] [PubMed]

98. Liu, P.; Nester, E.W. Indoleacetic acid, a product of transferred DNA, inhibits vir gene expression and growth of Agrobacterium tumefaciens C58. Proc. Natl. Acad. Sci. USA 2006, 103, 4658-4662. [CrossRef] [PubMed]

99. Ma, Y.; Oliveira, R.S.; Freitas, H.; Zhang, C. Biochemical and molecular mechanisms of plant-microbe-metal interactions: Relevance for phytoremediation. Front. Plant Sci. 2016, 7, 918. [CrossRef] [PubMed]

100. Ashraf, M.A.; Hussain, I.; Rasheed, R.; Iqbal, M.; Riaz, M.; Arif, M.S. Advances in microbe-assisted reclamation of heavy metal contaminated soils over the last decade: A review. J. Environ. Manag. 2017, 198, 132-143. [CrossRef] [PubMed]

101. Edwards, S.J.; Kjellerup, B.V. Applications of biofilms in bioremediation and biotransformation of persistent organic pollutants, pharmaceuticals/personal care products, and heavy metals. Appl. Microbiol. Biotechnol. 2013, 97, 9909-9921. [CrossRef] [PubMed]

102. Carpio, I.E.M.; Machado-Santelli, G.; Sakata, S.K.; Ferreira Filho, S.S.; Rodrigues, D.F. Copper removal using a heavy-metal resistant microbial consortium in a fixed-bed reactor. Water Res. 2014, 62, 156-166. [CrossRef] [PubMed]

103. Neu, T.R.; Lawrence, J.R. Advanced techniques for in situ analysis of the biofilm matrix (structure, composition, dynamics) by means of laser scanning microscopy. Methods Mol. Biol. 2014, 1147, $43-64$. [PubMed]

104. Kelly, J.J.; Minalt, N.; Culotti, A.; Pryor, M.; Packman, A. Temporal variations in the abundance and composition of biofilm communities colonizing drinking water distribution pipes. PLoS ONE 2014, 9, e98542. [CrossRef] [PubMed]

105. Silver, S. Bacterial Heavy Metal Detoxification and Resistance Systems. In Biotechnology and Environmental Science: Molecular Approaches; Mongkolsuk, S., Lovett, P.S., Trempy, J.E., Eds.; Springer: Boston, MA, USA, 1992; pp. 109-129, ISBN 978-0-585-32386-2. 
106. Syed, S.; Chinthala, P. Heavy Metal detoxification by different Bacillus species isolated from solar sSalterns. Scientifica 2015, 2015, 319760. [CrossRef] [PubMed]

107. Xu, L.; Shi, W.; Zeng, X.-C.; Yang, Y.; Zhou, L.; Mu, Y.; Liu, Y. Draft genome sequence of Arthrobacter sp. strain B6 isolated from the high-arsenic sediments in Datong Basin, China. Stand. Genom. Sci. 2017, 12, 11. [CrossRef] [PubMed]

108. Samanta, A.; Bera, P.; Khatun, M.; Sinha, C.; Pal, P.; Lalee, A.; Mandal, A. An investigation on heavy metal tolerance and antibiotic resistance properties of bacterial strain Bacillus sp. isolated from municipal waste. J. Microbiol. Biotechnol. Res. 2017, 2, 178-189.

109. Diels, L.; Mergeay, M. DNA Probe-mediated detection of resistant bacteria from soils highly polluted by heavy metals. Appl Environ. Microbiol. 1990, 56, 1485-1491. [PubMed]

110. Simmons, S.L.; DiBartolo, G.; Denef, V.J.; Goltsman, D.S.A.; Thelen, M.P.; Banfield, J.F. Population genomic analysis of strain variation in Leptospirillum Group II bacteria involved in acid mine drainage formation. PLoS Biol. 2008, 6, e177. [CrossRef] [PubMed]

111. Kuppusamy, S.; Thavamani, P.; Megharaj, M.; Lee, Y.B.; Naidu, R. Kinetics of PAH degradation by a new acid-metal-tolerant Trabulsiella isolated from the MGP site soil and identification of its potential to fix nitrogen and solubilize phosphorous. J. Hazard. Mater. 2016, 307, 99-107. [CrossRef] [PubMed]

112. Fan, J.; Zhang, B.; Zhang, J.; Ngo, H.H.; Guo, W.; Liu, F.; Guo, Y.; Wu, H. Intermittent aeration strategy to enhance organics and nitrogen removal in subsurface flow constructed wetlands. Bioresour. Technol. 2013, 141, 117-122. [CrossRef] [PubMed]

113. Skousen, J.; Zipper, C.E.; Rose, A.; Ziemkiewicz, P.F.; Nairn, R.; McDonald, L.M.; Kleinmann, R.L. Review of Passive Systems for Acid Mine Drainage Treatment. Mine Water Environ. 2017, 36, 133-153. [CrossRef]

114. Wildeman, T.R.; Duggan, L.; Phillips, P.; Rodriguez-Eaton, S.; Simms, R.; Bender, J. Passive treatment methods for manganese: Preliminary results from two pilot sites. The Challenge of Integrating Diverse Perspectives in Reclamation. In Proceedings of the 10th Annual National Meeting of the American Society of Surface Mining and Reclamation, Spokane, WA, USA, 16-19 May 1993; pp. 16-19.

115. Hedin, R.S.; Watzlaf, G.R.; Nairn, R.W. Passive treatment of acid mine drainage with limestone. J. Environ. Qual. 1994, 23, 1338-1345. [CrossRef]

116. Rose, A.W.; Dietz, J.M. Case studies of passive treatment systems: Vertical flow systems. In Proceedings of the 2002 National Meeting of the American Society of Mining and Reclamation, Lexington, KY, USA, 9-13 June 2002; pp. 776-797.

117. Younger, P.L. The adoption and adaptation of passive treatment technologies for mine waters in the United Kingdom. Mine Water Environ. 2000, 19, 84-97. [CrossRef]

118. Skousen, J.; Ziemkiewicz, P. Performance of 116 passive treatment systems for acid mine drainage. J. Am. Soc. Min. Reclam. 2005, 1100-1133. [CrossRef]

119. ITRC. The Interstate Technology \& Regulatory Council. Technical and Regulatory Guidance Document for Constructed Treatment Wetlands. 2003. The Interstate Technology \& Regulatory Council Wetland Team. Available online: https:/ / www.itrcweb.org/GuidanceDocuments/WTLND-1.pdf (accessed on 30 July 2018).

120. Sullivan, C.; Tyrer, M.; Cheeseman, C.R.; Graham, N.J.D. Disposal of water treatment wastes containing arsenic-A review. Sci. Total Environ. 2010, 408, 1770-1778. [CrossRef] [PubMed]

121. Swash, P.M.; Monhemius, A.J. Characteristics and stabilities of residues from the Wheal Jane constructed wetlands. Sci. Total Environ. 2005, 338, 95-105. [CrossRef] [PubMed]

122. Gadepalle, V.; Ouki, S.; Herwijnen, R. Immobilization of heavy metals in soil using natural and waste materials for vegetation establishment on contaminated sites. Soil Sediment Contam. 2007, 16, $233-251$. [CrossRef]

(C) 2018 by the authors. Licensee MDPI, Basel, Switzerland. This article is an open access article distributed under the terms and conditions of the Creative Commons Attribution (CC BY) license (http:/ / creativecommons.org/licenses/by/4.0/). 